\title{
Petrographic features of Siluro-Devonian felsic volcanic rocks in the Riley Brook area, Tobique Zone, New Brunswick: implications for base metal mineralization at Sewell Brook
}

\author{
R.A. Wilson \\ Department of Natural Resources and Energy, Geological Surveys Branch, P.O. Box 6000, \\ Fredericton, New Brunswick E3B 5H1, Canada
}

Date Received July 4, 1991

Date Accepted January 7, 1992

The Sewell Brook volcanogenic massive sulphide deposit is the first mineral deposit of economic significance to be found within the Tobique Zone of the Matapédia Cover Sequence in northwestern New Brunswick. Tobique Zone strata belong to the Lower Devonian Tobique Group, which consists of sedimentary and bimodal volcanic rocks that were deposited in a predominantly subaqueous environment. In the Riley Brook area, volcanic rocks can be assigned to four major suites that consist of variable proportions of felsic and mafic volcanic and sedimentary rocks: the River Dee, Gulquac Mountains, Black Mountains, and Blue Mountains suites. The Sewell Brook deposit is spatially associated with felsic volcanic rocks of the Gulquac Mountains suite. Felsic volcanic rocks form large composite piles that comprise several rhyolitic facies, including massive rhyolite, perlitic and devitrified (glassy) rhyolites, altered glassy rhyolites displaying pseudo-fragmental textures, felsic hyaloclastites, and minor pyroclastic rocks. The spatial association of these facies is interpreted as reflecting their respective horizons within subaqueous felsic flows or domes: massive rhyolite occupies the central, relatively slow-cooling parts of flows or domes, whereas perlitic and spherulitic textures predominate in the more rapidly cooled outer parts.

Textural characteristics of felsic volcanic rocks in the Riley Brook area can be used to support the interpreted subaqueous setting, and as a guide to potential mineralization. Textural changes imposed by perlitic fracturing and devitrification of glassy rhyolites resulted in the increased permeability of large volumes of volcanic rock. Circulation of hydrothermal fluids through permeable glassy lavas and through spatially-related porous hyaloclastites produced widespread chloritic and sericitic alteration and favored the generation of sulphide deposits. At Sewell Brook, the massive sulphide lens overlies and is hosted in part by hyaloclastic microbreccias spatially associated with texturally modified glassy rhyolites.

Le gisement volcanogène de sulfures massifs du ruisseau Sewell est le premier gisement à potentiel économique découvert dans la zone de Tobique de la séquence de recouvrement de Matapédia, dans le nord-ouest du NouveauBrunswick. Les roches de la zone de Tobique appartiennent au Groupe de Tobique, d'âge Dévonien précoce, qui consiste en des roches sédimentaires et des volcanites bimodales déposées principalement en milieu subaquatique. Dans la région du ruisseau Riley, les roches volcaniques se divisent en quatre suites composées de proportions variables de volcanites felsiques et mafiques et de roches sédimentaires: les suites de la rivière Dee, des monts Gulquac, des monts Black et des monts Blue. Le gisement du ruisseau Sewell est spatiallement associé aux volcanites felsiques de la suite des monts Gulquac. Les volcanites felsiques forment de grands empilements composites qui comprennent plusieurs faciès rhyolitiques dont les rhyolites massives, les rhyolites perlitiques et dévitrifiées (vitreuses), les rhyolites vitreuses altérées à textures pseudo-clastiques, les hyaloclastites felsiques et des roches pyroclastiques moins abondantes. L'association spatiale de ces faciès est interprétée comme reflétant leur position respective dans les coulées ou les dômes subaquatiques; ainsi, les rhyolites massives occupent la partie centrale des coulées ou dômes, qui a connu un refroidissement relativement lent, tandis que les textures perlitiques et sphérolitiques dominent dans les zones marginales à refroidissement plus rapide.

Les caractéristiques texturales des volcanites felsiques dans la région du ruisseau Riley peuvent être utilisées pour appuyer l'hypothèse d'un milieu subaquatique et comme guide d'exploration. Les changements texturaux causés par les fractures perlitiques et la dévitrification des rhyolites vitreuses ont amené une augmentation de la perméabilité de grands volumes de roche volcanique. La circulation de fluides hydrothermaux à travers les laves vitreuses perméables et des hyaloclastites poreuses à proximité ont produit des zones d'altération en chlorite et en séricite étendues et ont favorisé la formation de gisements de sulfures. Au ruisseau Sewell, la lentille de sulfures massifs gît au-dessus et au sein de microbrèches hyaloclastiques spaciallement associées à des rhyolites vitreuses à texture modifiée.

[Traduit par le journal] 


\section{INTRODUCTION}

The Sewell Brook volcanic-hosted sulphide deposit is the most significant mineral deposit yet discovered within the Siluro-Devonian Tobique-Chaleur belt of northwestern New Brunswick (Fig. 1). Like the Ordovician Tetagouche Group, which hosts about 35 base-metal deposits with defined tonnage to the north and east (McCutcheon, 1990), the Tobique-Chaleur belt comprises a thick sequence of interbedded sedimentary and bimodal volcanic rocks; however, sporadic exploration during the last 30 years has been largely unsuccessful, creating the impression that the Siluro-Devonian rocks were likely to remain unproductive. In recent years, regional mapping and lithogeochemistry in the Riley Brook area led to the identification of several new base metal/ precious metal prospects (Wilson, 1988); the Sewell Brook occurrence has proved to be the most important of these. To date, the results of diamond drilling at Sewell Brook indicate that reserves in the high-grade main sulphide zone may be relatively small; nevertheless, the geology of the deposit and its context within the regional geological framework suggest that the Riley Brook area is prospective for hosting additional similar deposits. It is hoped that the observations and interpretations of the geological features of the area presented herein will serve as a useful guide to the ongoing exploration efforts.

Previous investigations of the bedrock geology of the Tobique region include published geological maps by Anderson (1962), Irrinki (1977a, b, c, d), St. Peter $(1978,1979$, 1981) and Wilson (1990). However, few descriptions of the Siluro-Devonian stratigraphy have been published, exceptions being reports on the geology of the Wapske area to the south of the Sewell Brook deposit (St. Peter, 1978, 1979), and a brief outline of the geology of the Riley Brook area by Wilson (1989). The objective of this paper is to provide a summary description of the lithologies present in the Riley Brook area, with emphasis on those petrologic features of the felsic volcanic rocks that have a bearing on mineralization at Sewell Brook.

\section{Regional Geological Setting}

New Brunswick has been divided into a number of preTaconic terranes of contrasting tectonic styles and lithostratigraphic facies that are overlain by post-Taconic cover sequences (Fyffe and Fricker, 1987). Northwestern New Brunswick is underlain by Upper Ordovician to Lower Devonian rocks of the Matapédia Cover Sequence (Fig. 1), which in turn is divided into several zones (e.g., Davies, 1979). The easternmost part of the Matapédia Cover Sequence is underlain by Upper Silurian to Lower Devonian volcanic and sedimentary rocks that comprise the Chaleur and Tobique zones. The Chaleur Zone occupies the area between Chaleur Bay and the Rocky Brook-Millstream fault, whereas the Tobique Zone extends southwestward from the Rocky Brook-Millstream fault, across western New Brunswick. The Siluro-Devonian rocks of the Tobique Zone are

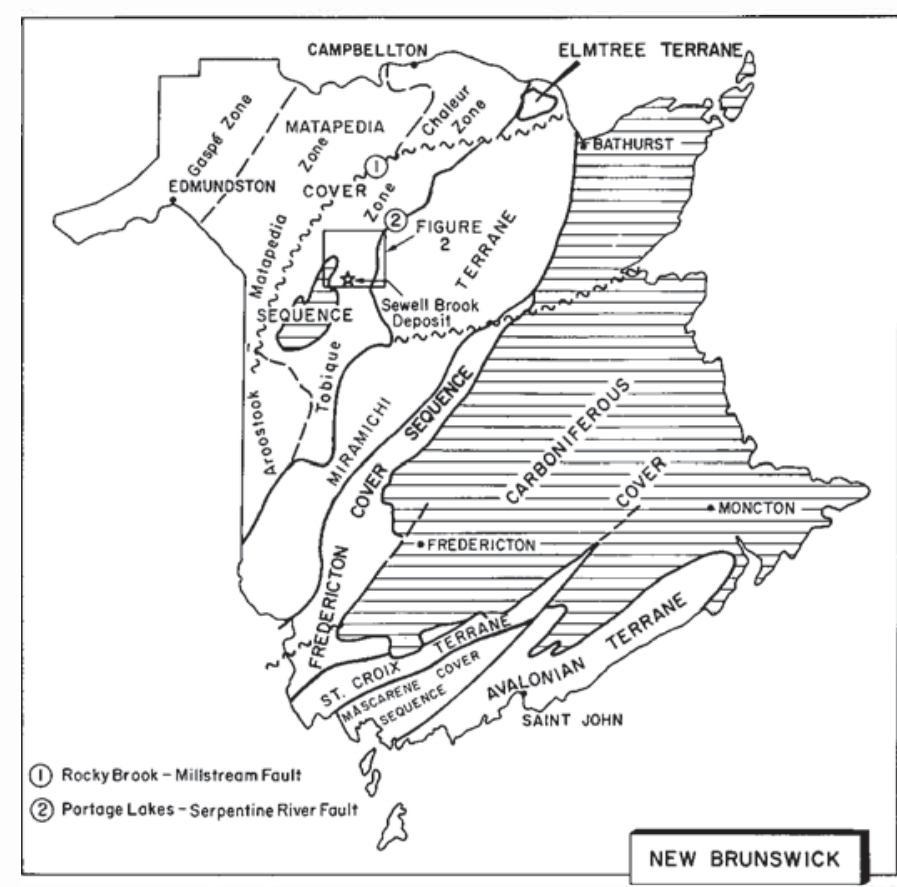

Fig. 1. Location map showing tectonostratigraphic terranes and cover sequences of New Brunswick (modified after Fyffe and Fricker, 1987). The Elmtree Terrane is underlain by Ordovician oceanic crust. The Miramichi and St. Croix terranes are sedimentary and volcanic rocks generated in an arc-back-arc setting. The Avalon Terrane comprises mainly Precambrian volcanic-arc rocks. The Matapédia, Fredericton and Mascarene Cover sequences are sedimentary and volcanic rocks that were deposited between the Late Ordovician and Early Devonian. Location of Riley Brook area (Fig. 2) and Sewell Brook deposit are shown.

generally juxtaposed against Upper Ordovician to Lower Silurian calcareous flysch of the Aroostook-Matapédia Zone along the Rocky Brook-Millstream Fault, but conformable relationships between the two zones are preserved in the southwest (Fig. 1). The Tobique Zone is juxtaposed against Cambro-Ordovician quartzites and schists of the Miramichi Terrane along the Portage Lakes-Serpentine River fault system (Figs. 1, 2).

Except for outliers of flat-lying Carboniferous rocks, all the volcanic and sedimentary rocks in the Tobique Zone are assigned to the Tobique Group (St. Peter, 1978). In its type area, i.e., in the Wapske River region south of the Riley Brook area, the Tobique Group has been divided into the Costigan Mountain and Wapske formations (St. Peter, 1978). Mapping by Wilson $(1989,1990)$ has established that this nomenclature cannot be meaningfully extended into the Riley Brook area (Fig. 2) because of complex interfingering and pinching-out of volcanic and sedimentary units.

\section{Geology of the Riley Brook Area}

Volcanic rocks of the Tobique Group underlie NE-SWtrending belts that are lenticular in outline and variable in extent and width. Four major composite volcanic piles, comprising variable proportions of felsic and mafic rocks and 

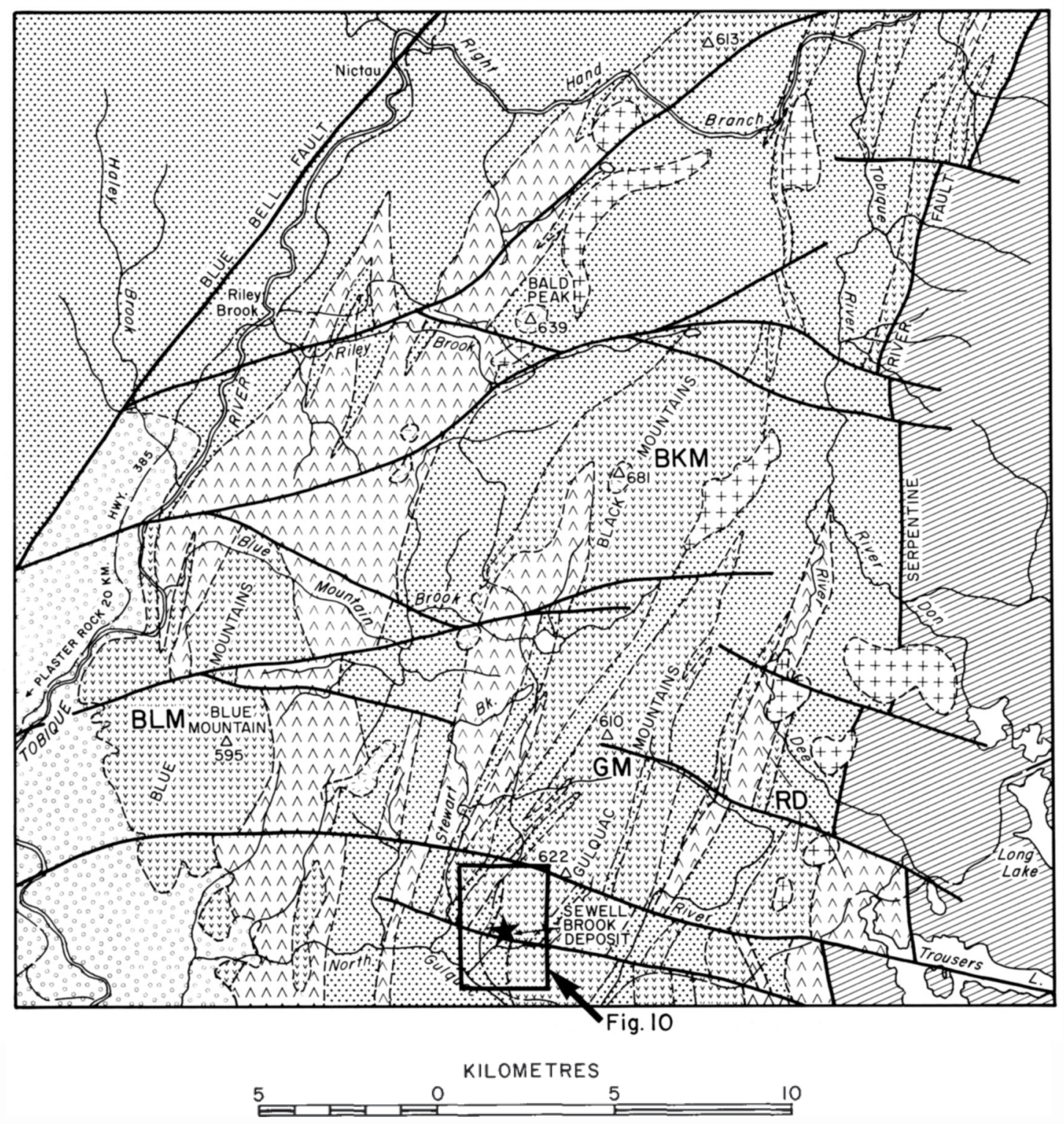

\section{LEGEND}

MISSISSIPPIAN
LOWER DEVONIAN
$\begin{aligned} & ++++ \\ & ++++\end{aligned}$ Gabbro
Felsic subvolcanic intrus/ve rocks
Siltstone, sandstone, minor slate,
conglomerate

Felsic volcanic rocks
CAMBRO-ORDOVICIAN
Quartzite, schist
Fault
- Geological contact

Fig. 2. Generalized geology of the Riley Brook area. Volcanic suites labelled on map include RD - River Dee suite, GM - Gulquac Mountains suite, BKM - Black Mountains suite, and BLM - Blue Mountains suite.

separated by narrow units of marine sedimentary rocks, can be recognized. Henceforth, these composite volcanic units will be referred to as suites, the connotation being essentially coeval piles of volcanic rocks, as opposed to the meaning of this term as a lithodemic unit under the North American
Stratigraphic Code. From east to west, or oldest to youngest, these are: (1) the River Dee suite, consisting of several narrow discontinuous units of mafic and felsic volcanic rocks in roughly equal proportion; (2) the Gulquac Mountains suite, consisting of a large felsic volcanic pile with minor 
intercalated mafic volcanic and sedimentary rocks; (3) the Black Mountains suite, consisting of a large felsic volcanic unit, a lesser quantity of mafic volcanic rocks, and minor sedimentary rocks; and (4) the Blue Mountains suite, which consists of a comparatively large unit of mafic volcanic rocks that partially envelops a large ellipsoidal unit of felsic volcanic rock. The Sewell Brook deposit is hosted by sedimentary and felsic volcanic rocks of the Gulquac Mountains suite.

The volcanic and sedimentary rocks of the Tobique Group are predominantly subaqueous. The sedimentary rocks contain fossils and bedforms typical of sediments deposited in relatively shallow marine conditions. Pillow basalts and hyaloclastites are common in the mafic volcanic units. Subaqueous emplacement of felsic volcanic rocks, except for the Blue Mountains suite, is inferred from intercalations of marine sedimentary rocks, and from macroscopic and microscopic textural styles as described below.

Felsic volcanic rocks will be described in considerably greater detail than mafic volcanic or sedimentary rocks, because of the textural variety present as well as their close spatial association with the mineralization at Sewell Brook. In texturally heterogenous volcanic rocks such as those in the Riley Brook area, recognition of specific features can be a valuable guide to identification of prospective horizons. Unfortunately, outcrop exposure is generally not sufficient to permit mapping-out of individual facies as separate (sub)units, or the observation of contact relationships; rapid lateral and vertical facies changes exacerbate this difficulty.

\section{Sedimentary Rocks}

Sedimentary rocks of the Tobique Group comprise grey to green, thin- to medium-bedded siltstones and fine- to medium-grained sandstones, slaty siltstones, and minor volcaniclastic sediments and quartz-pebble conglomerates. Sequences of massive, thick-bedded sandstone or siltstone are locally present. Bedforms include graded, parallel-laminated and local cross-laminated beds. Bedding plane contacts are normally planar though erosive contacts exist where thin beds of medium- to coarse-grained lithic sandstone record sudden influxes of volcaniclastic material. Fossiliferous beds are common; the faunal assemblages (mainly brachiopods and trilobites) have been assigned an Early Devonian (Gedinnian-Siegenian) age by Boucot (personal communication), who also interpreted them as representing a Benthic Assemblage 3 community, occupying water depths up to $100 \mathrm{~m}$. Pickerill (1986), in contrast, interpreted bedforms and trace fossil assemblages as evidence of deposition below storm wavebase in an outer slope environment (up to $200 \mathrm{~m}$ depth). In any event, deep water conditions did not prevail and water depths did not exceed $200 \mathrm{~m}$.

\section{Mafic Volcanic Rocks}

Mafic volcanic lithotypes and textures are similar in all volcanic suites, and include massive to pillowed, commonly vesicular, or (rarely) porphyritic basalts $\left(<52 \% \mathrm{SiO}_{2}\right)$, and local hyaloclastites and basaltic tuffs. Textures of massive and pillowed basalts are most commonly intergranular, but vary to pilotaxitic or (in glassy varieties) hyalopilitic. Basalts typically feature a spilitic mineralogy characterized by albitized plagioclase laths (50-80\%), chlorite (10-25\%) and FeTi oxides (up to 20\%) plus minor calcite, titanite (sphene) and locally epidote. Clinopyroxene (augite) is present in amounts up to $40 \%$ in places, but is rarely preserved, having instead been altered to chlorite, titanite, oxides and/or epidote. Plagioclase phenocrysts, when present, rarely exceed $15 \%$, and may be up to $1 \mathrm{~cm}$ in size.

Mafic fragmental rocks consist of lapilli tuffs and hyaloclastites. Basaltic tuffs typically contain fragments of scoria that are irregular to lenticular in shape, and somewhat glassy when seen in thin section. Mafic hyaloclastites are spatially associated with pillow basalts and typically consist of angular fragments of sub-opaque basaltic glass that often feature a concentric structure parallel to the fragment rims. Palagonitic alteration has been noted in some hyaloclastites in the Riley Brook area.

Mafic volcanic rocks are mainly, and perhaps entirely emplaced underwater. Pillow structures, spilitic mineralogy (generally interpreted as a seafloor alteration effect), hyaloclastic textures and local palagonitic alteration are all characteristic of subaqueous deposition (Fisher and Schmincke, 1984). The glassy nature of the scoriaceous fragments in basaltic tuffs is consistent with rapid chilling in seawater following ejection from the vent; these tuffs may represent shallow water, maar-type eruptions (Fisher and Schmincke, 1984).

\section{Felsic Volcanic Rocks}

The River Dee, Gulquac Mountains and Black Mountains volcanic suites include variable proportions of several felsic lithotypes that are characterized by distinct textural styles. The narrow felsic units underlying the northeastern and north-central parts of the Riley Brook area (Fig. 2) are petrologically similar to these three suites and are grouped with them for simplicity. The Blue Mountains suite is unique, in part because of its relative textural homogeneity, and will therefore be treated separately.

Felsic volcanic rocks of the River Dee, Gulquac Mountains, and Black Mountains suites are dark grey to green, massive to flow-banded, aphyric to feldspar-phyric, locally vesicular rhyolites $\left(>70 \% \mathrm{SiO}_{2}\right)$. Perlitic or spherulitic textures reflecting an originally glassy state are widespread; locally, perlitic and devitrified rhyolites feature apparent fragmental textures that can be attributed to post-depositional alteration, as described below. A distinctive facies of microbrecciated rhyolite is locally present and shows a close spatial relationship to the glassy rhyolites.

In thin section, rhyolites are observed to be aphanitic to porphyritic with a microlitic to microfelsitic groundmass. Potassium-feldspar phenocrysts are euhedral to subhedral and vary in size and abundance within individual flow units, 
but rarely exceed $3 \mathrm{~mm}$ in size and $15 \%$ by volume. Sericite alteration is common and totally replaces potassium feldspar in some cases. Perlitic fracturing and devitrification textures (Figs. 3, 4) are widespread, indicating chilling of large volumes of felsic lava to a glassy state. Although similar textures are seen in some ignimbrites, the exceptional abundance of perlitic and devitrified rhyolites in the Riley Brook area suggests that these rocks do not represent the strongly welded central zones of subaerial ignimbritic flows. Furthermore, neither the perlitic/devitrified rhyolites nor rhyolites spatially associated with them contain fiamme, bubble-wall shards, lithic fragments or shattered phenocrysts, nor do they exhibit the geometry and bedforms that characterize subaerial ash flow deposits (Ross and Smith, 1961; Sheridan, 1979; Wright et al., 1980). Perlitic and spherulitic rhyolites commonly display chloritic or sericitic alteration (Fig. 3b,d), reflecting the increased permeability to circulating fluids made possible by perlitic fracturing and by the slight volume change that accompanies devitrification. In thin section, phyllosilicate alteration is seen to follow perlitic cracks and replace the original glass so that the primary texture is progressively destroyed (e.g., Fig. 3b). In many cases, devitrification of perlitic rhyolites tends to further obscure primary perlitic textures (Fig. 3c,d).

Two types of devitrification textures are observed in the glassy rhyolites: classic fibro-radial or bow-tie spherulites (Fig. 4a,b), and small, closely-packed patches of micropoikilitic quartz (Fig. 4c,d). Micropoikilitic quartz texture is as described by Lofgren (1971); that is, it consists of a random to fibro-radial pattern of feldspar "microlites" enclosed in quartz; the host quartz crystals have unique extinction positions and occur as a mosaic-like patchwork with complex grain interfaces. Devitrification is complete in many samples of glassy rhyolite, but in others the spherulites or micropoikilitic quartz patches form a mottled pattern consisting of small, isolated felsitic "granules" that in places have coalesced into larger domains characterized by bulbous or colloform, nebulous margins (the "orb" texture of Lofgren, 1971) (Fig. 5). In these rocks, chloritic alteration permeates the areas interstitial to the granules or orbs: these areas are interpreted as remnant patches of undevitrified glass that were subsequently chloritized. Locally, coalescing devitrification fronts leave small, lenticular patches that can look very much like fiamme (Fig. 5a). The seminal work of Allen (1988) contains a thorough description of these "pseudofragmental" or false pyroclastic textures, and the reader is referred to his paper for details of the alteration processes. The true nature of these rocks can be most readily recognized in porphyritic varieties, in which feldspar phenocrysts are clearly observed to straddle the interface between the apparent "fragments" (chloritic, altered-glass domain) and "groundmass" (felsitic, devitrified-recrystallized domain) (Fig. 5b,d).

Massive to flow-banded, perlitic or devitrified rhyolites are locally transitional from a zone of in situ brecciation into a distinctive finely brecciated rock consisting of angular fragments of rhyolite in a vitric matrix of finely granulated felsitic material (Fig. 6a,b,c). Both fragments and ground- mass commonly show moderate to extensive sericitic or chloritic alteration. Isolated outcrops of brecciated and/or glassy rhyolite are locally exposed within sequences that consist predominantly of these "microbreccias". Microbreccias exhibit several features that allow them to be distinguished from classic pyroclastic rocks (e.g., Fig. 6d): (1) the fragments are monomict, consisting entirely of rhyolite; textures within these fragments, however, may be perlitic, spherulitic, vesicular, or flow-banded; (2) no welding or flattening of fragments or groundmass has occurred; (3) pumice is absent; (4) the groundmass contains no bubblewall shards or spicules typical of explosive eruptions of rapidly vesiculating lava; and (5) no primary bedforms such as those characterizing ash flows, ash falls, etc., are observed. Medium - to coarse-grained, typically chloritic volcaniclastic rocks containing scattered, rounded clasts of perlitic, spherulitic or banded rhyolite generally overlie units of microbreccia and are therefore probably beds of reworked microbreccia. These volcaniclastic rocks are also locally intercalated with siltstone or sandstone beds. The microbreccia facies is particularly significant at Sewell Brook, where these rocks occupy the footwall to the sulphide zone and locally host sulphide mineralization.

Rhyolites of the Blue Mountains suite are distinctive in several respects, for example: (1) they are reddish-maroon in colour, (2) quartz phenocrysts are more abundant, and (3) hyaloclastites, perlitic and "false pyroclastic" textures and chloritic alteration are absent. Blue Mountains rhyolites are typically massive to flow-banded, porphyritic and locally vesicular; their colour is derived from a very fine hematitic dust that constitutes 5 to $10 \%$ of most samples. Phenocrysts include potassium feldspar (5-15\%) and quartz (0-15\%). Quartz crystals are typically embayed and in places are more abundant than feldspar, though they are locally absent. Devitrification textures abound, but unlike the other three suites no perlitic textures were observed in the Blue Mountains rhyolites. Devitrification is manifest in two main forms: as classic fibro-radial spherulites, and as mosaic-like patches of micropoikilitic quartz. Relatively coarse aggregates of vapour-phase quartz commonly occupy angular spaces created by devitrification. Pumiceous lapilli tuffs or lithic-vitric lapilli tuffs are present locally; the petrography of pyroclastic rocks is similar to that of lapilli tuffs in the other felsic suites, except for the greater abundance of quartz crystals. The textural characteristics of the Blue Mountains rhyolites are interpreted as evidence of subaerial emplacement, in contrast to the subaqueous environment that is indicated for all other felsic volcanic rocks in the Riley Brook area.

Pyroclastic rocks are volumetrically the least important of the volcanic facies present in the Riley Brook area; they are found at scattered locations within all felsic suites but appear to be relatively more abundant in the Black Mountains and Blue Mountains suites. Pyroclastic rocks comprise vitriccrystal (e.g., Fig. 6d), vitric-lithic, and pumiceous vitric lapilli tuffs. The main features of pyroclastic rocks which distinguish them from hyaloclastites are a polymict lithic fragment assemblage and a vitric groundmass of bubble-wall 

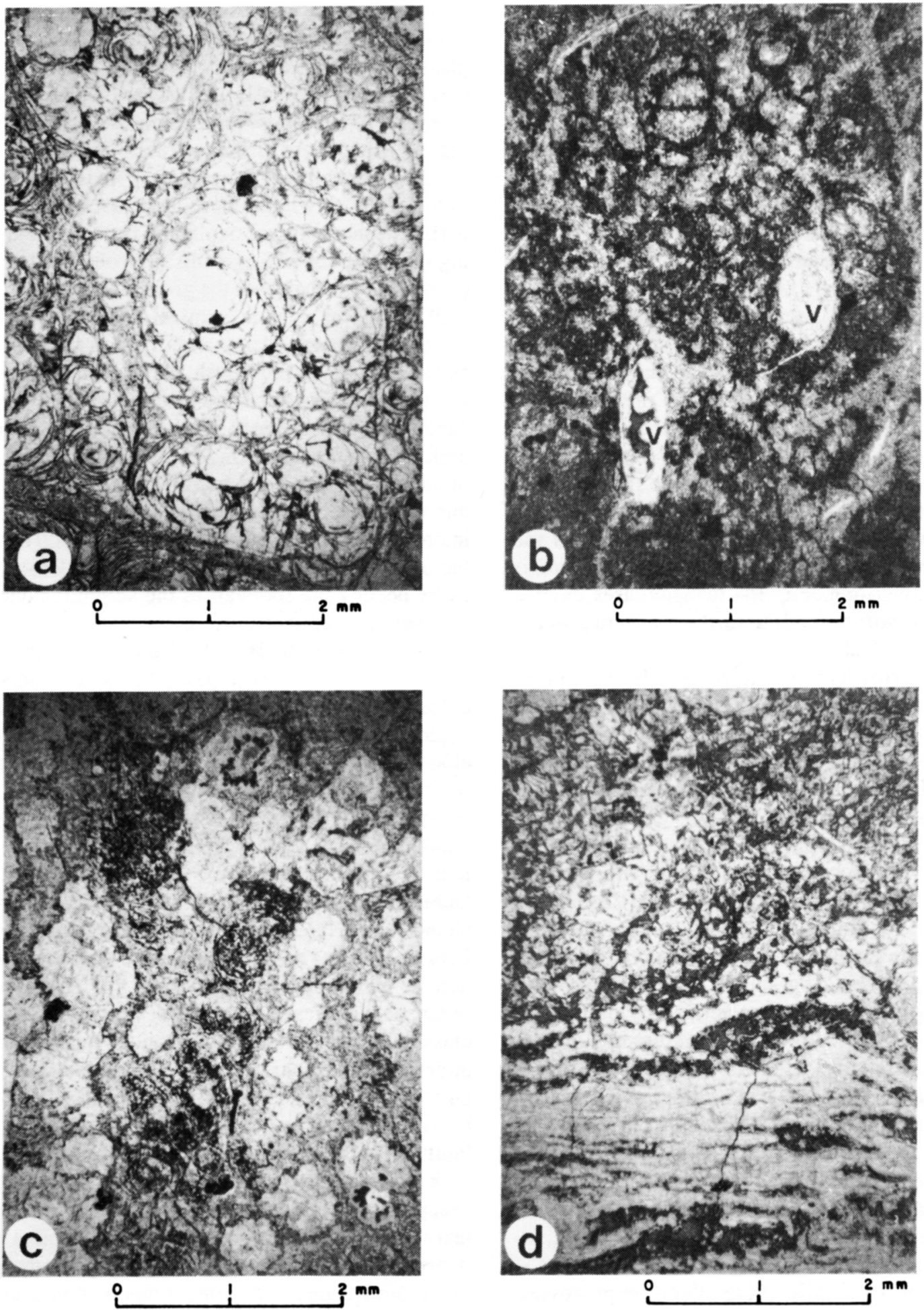

Fig. 3. (a) Photomicrograph of fresh perlitic fracture pattern in glassy rhyolite; p.p. light. (b) Photomicrograph showing vesicles (v) in a chloritized perlitic groundmass; p.p. light. (c) Photomicrograph of perlitic, spherulitic rhyolite, with local chloritic alteration (dark patches); perlitic texture has been partially obliterated by spherulitic devitrification and recrystallization (lighter patches); p.p. light. (d) Photomicrograph of devitrification and perlitic fracture in altered, flow-banded rhyolite. Spherulites form chains aligned along flowbands (bottom); relict perlitic fracture pattern (top) is almost destroyed by chloritic alteration and devitrification; p.p. light.

shards and spicules. Essential pyroclasts are pumice lapilli and crystals or crystal fragments. Shattering of feldspar crystals is not extensive and it is not unusual for euhedral crystals to be present, suggesting low-energy eruptions per- haps because of low volatile content in the magma. In terms of crystal content, pyroclastic rocks reflect the mineralogy of the rhyolite flows described above, as feldspar crystals are typically present but quartz crystals are not common. Cog- 

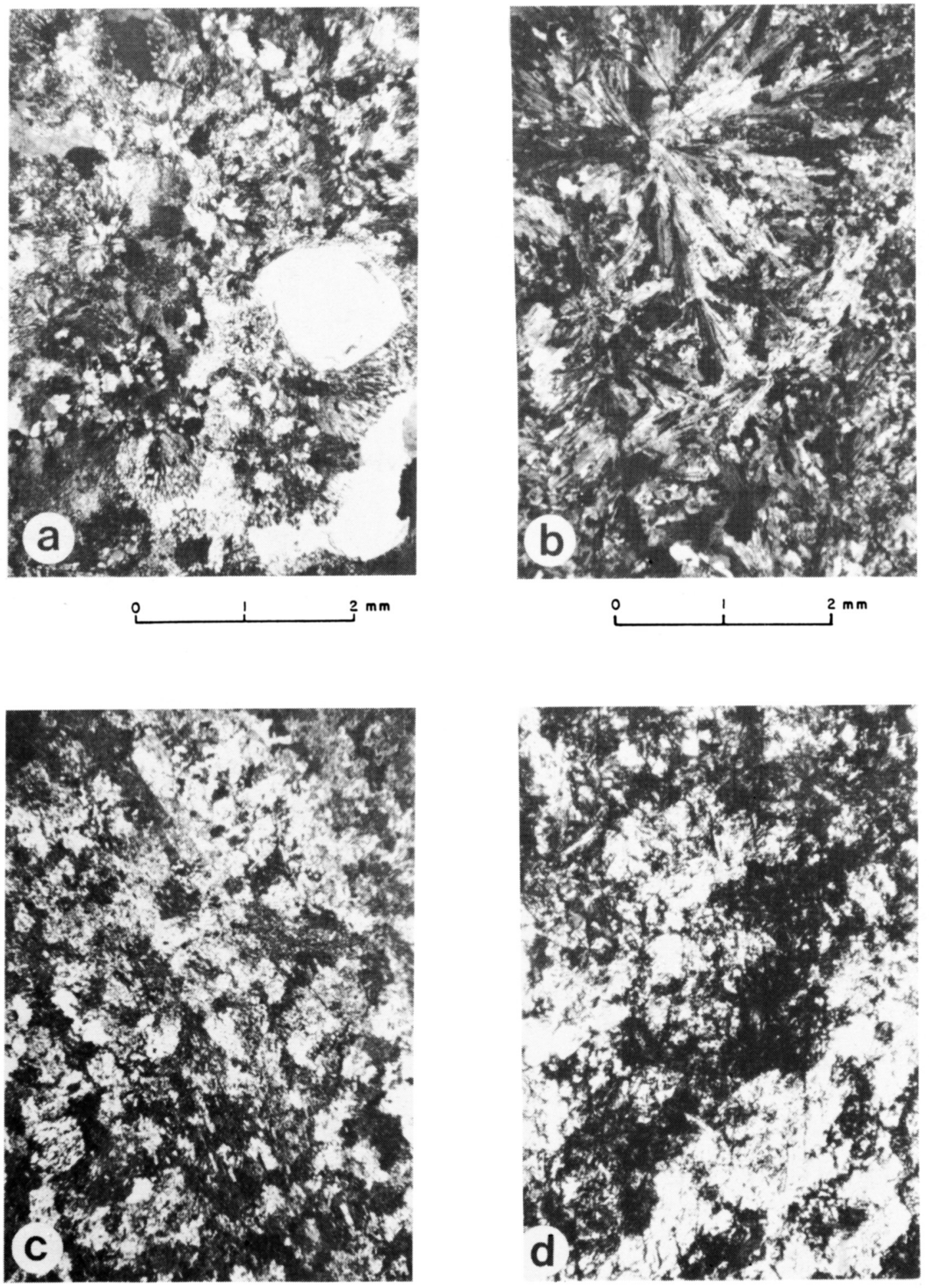

\section{0}

$2 \mathrm{~mm}$

i m m

Fig. 4. Devitrification textures in rhyolite. (a) Photomicrograph of fibro-radial spherulites in quartz-phyric rhyolite; recrystallization has produced a fine-grained granophyric intergrowth; x.p. light. (b) Photomicrograph of bow-tie, sheaf-like spherulites; x.p. light. (c) Photomicrograph of massive glassy rhyolite devitrified in a micropoikilitic quartz-patchwork style (see text); x.p. light. (d) Photomicrograph of texture in (c) in more detail showing spherulite-like fibro-radial network of microlitic feldspar inclusions in quartz; dark areas are extinguished patches of micropoikilitic quartz; x.p. light.

nate or accessory lithic clasts commonly include fragments of perlitic, spherulitic, or flow-banded rhyolite derived from underlying lava flows. In pumiceous lapilli tuffs, pumice lapilli are characterized by random orientations and minimal 


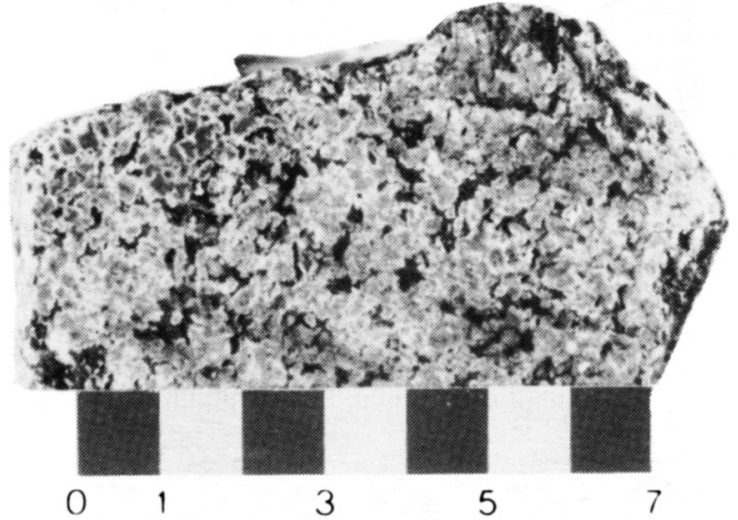

a CENTIMETRES

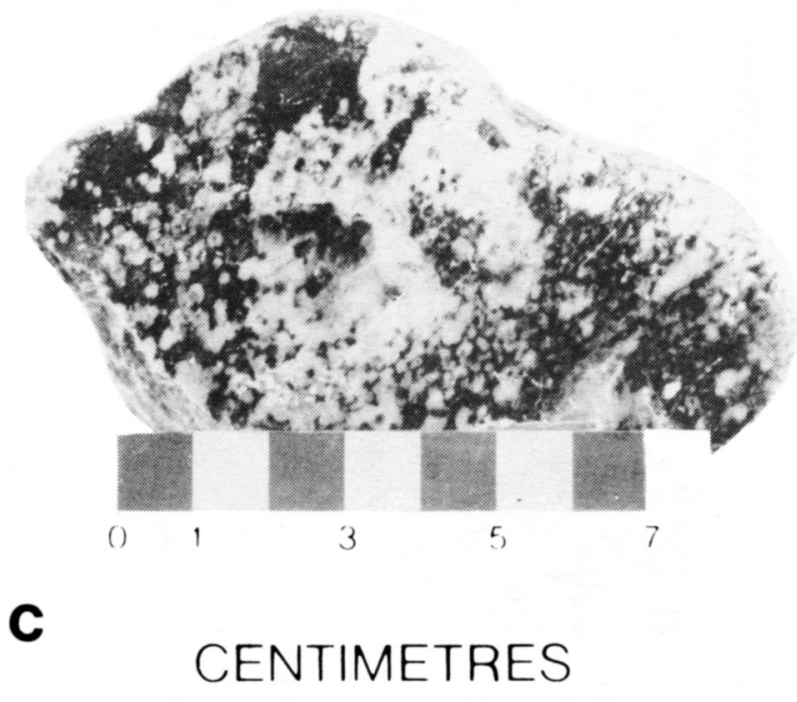

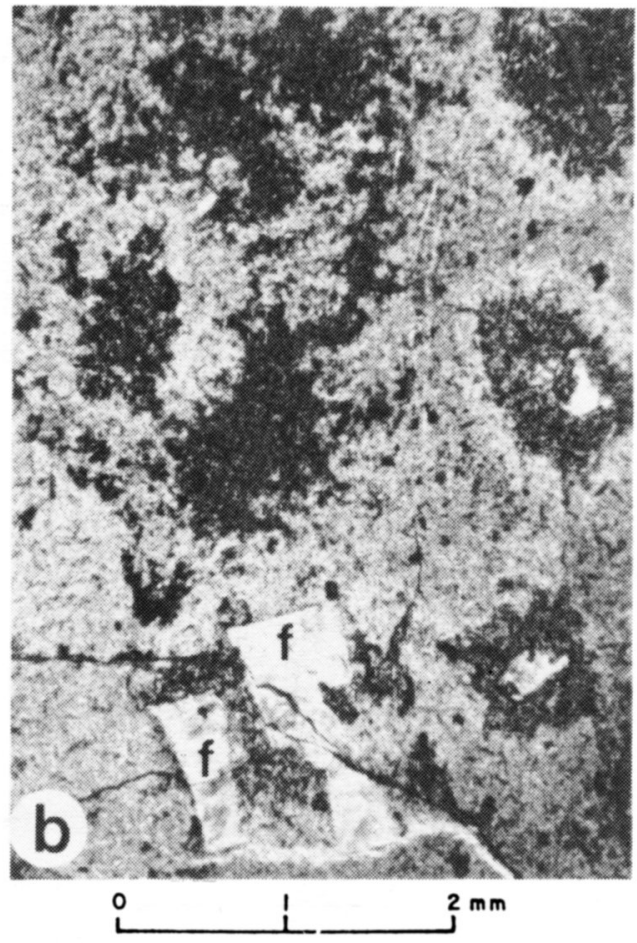

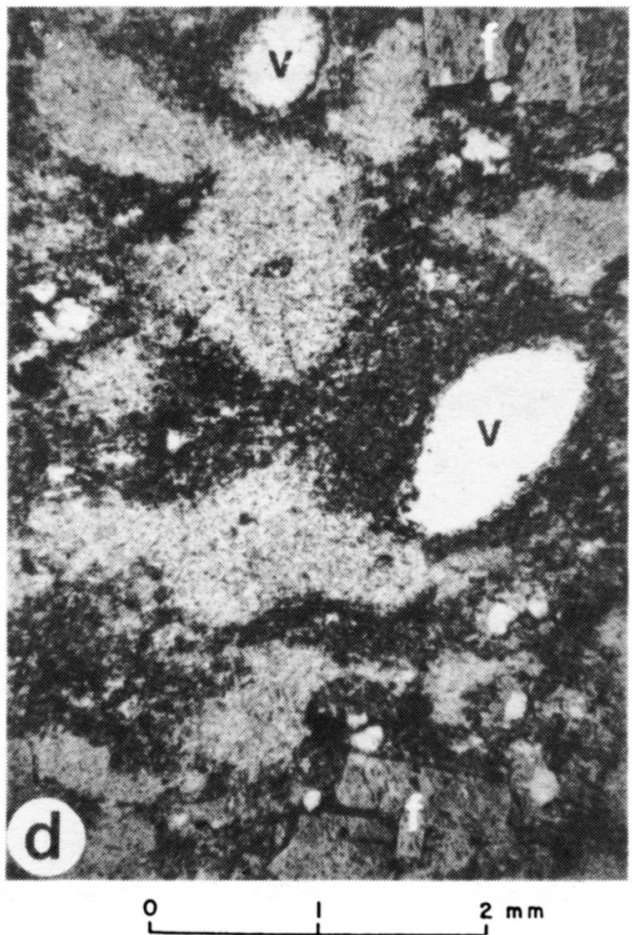

Fig. 5. Pseudo-fragmental textures in altered, devitrified and perlitic rhyolites. (a) Chloritic, fiamme-like "fragments" in felsic volcanic rock. (b) Photomicrograph of texture in (a) reveals that the "fragments" (dark patches) are merely ill-defined areas of chloritic alteration interstitial to devitrified/recrystallized domains (light areas); feldspar crystals (f) overlap the chloritic and felsitic areas; p.p. light. (c) Mottled, apparent fragmental texture in felsic volcanic rock. (d) Photomicrograph of (c) shows well-developed "orb" texture consisting of spherulitic devitrified domain (light areas) and chloritic, altered-glass domain (dark areas); some euhedral feldspar crystals (f) overlap these domains; a few vesicles ( $v$ ) are also present; p.p. light. 

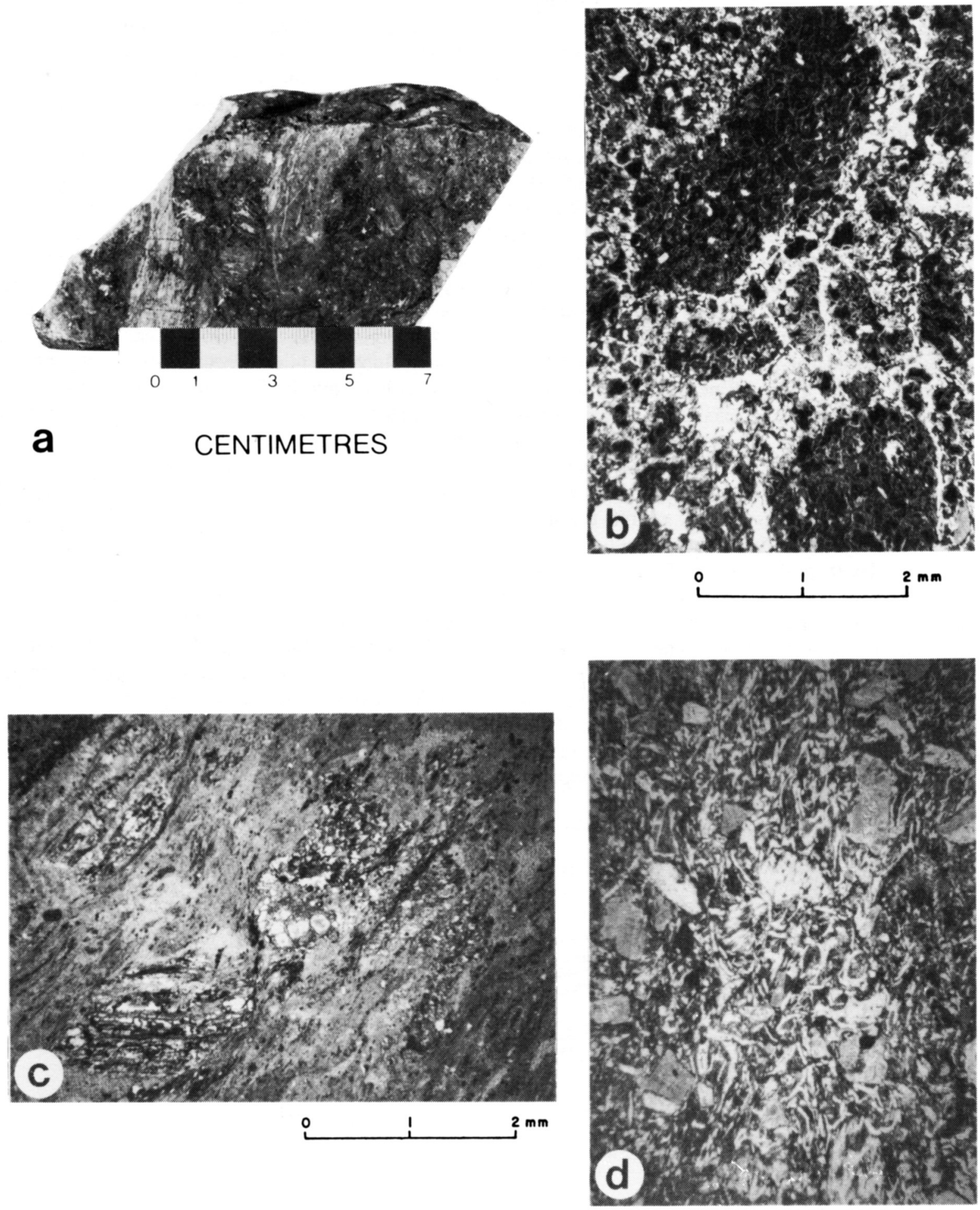

운 $2 \mathrm{~mm}$

Fig. 6. (a) Hand specimen of hyaloclastic microbreccia. (b,c) Photomicrographs of hyaloclastic microbreccia, containing randomly oriented angular fragments of perlitic, spherulitic, or flow-banded rhyolite; (b) is chloritized, (c) is sericitized. (d) Photomicrograph of vitric-crystal tuff showing very shard-rich groundmass; p.p. light. 
flattening. This may be a result of subaqueous emplacement and consequent loss to seawater of the heat necessary to initiate welding (Fiske and Matsuda, 1964).

\section{Interpretation and Conceptual Model}

The large volume of glassy lavas and the local intercalation of thin interflow units of marine sedimentary rocks indicate that the felsic volcanic rocks of the River Dee, Gulquac Mountains and Black Mountains suites, like the mafic volcanic rocks, were emplaced in a subaqueous environment. The spatial relationships of the respective felsic volcanic facies within these suites can be explained in terms of a generalized model for subaqueous flow, shown schematically in Figure 7. The centre of the rhyolite dome or flow consists of massive, feldspar-phyric to aphyric, vesicle-poor rhyolite characterized by a crystalline (microlitic or microfelsic) groundmass. Near the margins of the flow where the lava interacted with sea water, glassy textures predominate, and perlitic and spherulitic (or micropoikilitic) textures result from hydration and crystallization, respectively, of the glass. Volatiles exsolved within the flow migrate toward the margins and accumulate there in a manner analogous to the migration of vesicles toward the rims of pillows in pillow basalts. Vesicles become stretched, and flow-laminations develop, as a result of shear flow near the margins of the lava body (de Rosen-Spence $e t$ al., 1980). The relatively small volume of crystalline (i.e., non-glassy) rhyolite in the Riley Brook area suggests that the average flow unit was fairly small, resulting in the more common development of those textures that characterize the outer, more rapidly cooled parts of lava flows. The fragmental rocks (microbreccias) spatially related to the glassy rhyolites are interpreted as a hyaloclastic facies that formed by the thermal-strain-induced shattering of the rapidly chilled margins of actively moving flows, as described by Pichler (1965), de Rosen-Spence et al. (1980) and Yamagishi and Dimroth (1985). The mechanism of formation of these rocks is essentially identical to that which produces mafic pillow breccias and hyaloclastites. The predominance of perlitic, spherulitic and to a lesser extent vesicular and flow-banded textures in the fragments comprising these hyaloclastic microbreccias, is a function of the prevalence of these textures near the margins of the flow units. Isolated bodies of glassy or brecciated rhyolite within hyaloclastite sequences probably represent lava lobes or tongues that became detached from the main part of a flow and incorporated in the microbreccia. It should be pointed out that hyaloclastic microbreccia does not appear to be associated with all rhyolite flow-units in the Riley Brook area; it is likely that specific physicochemical conditions are necessary for their formation, involving temperature, bulk composition, viscosity, and volatile content (e.g., Yamagishi and Dimroth, 1985).

\section{Structure and Metamorphism}

The volcanic and sedimentary rocks in the Riley Brook area trend NE-SW to NNE-SSW and parallel the regional strike of the Tobique Zone; they typically young and dip to the west, away from the fault contact with the Miramichi Terrane. However, bedding plane measurements in sedimentary rocks indicate that open to close folds are locally present, although the large felsic volcanic suites, being more competent, have been relatively unaffected. Most sedimentary rocks,

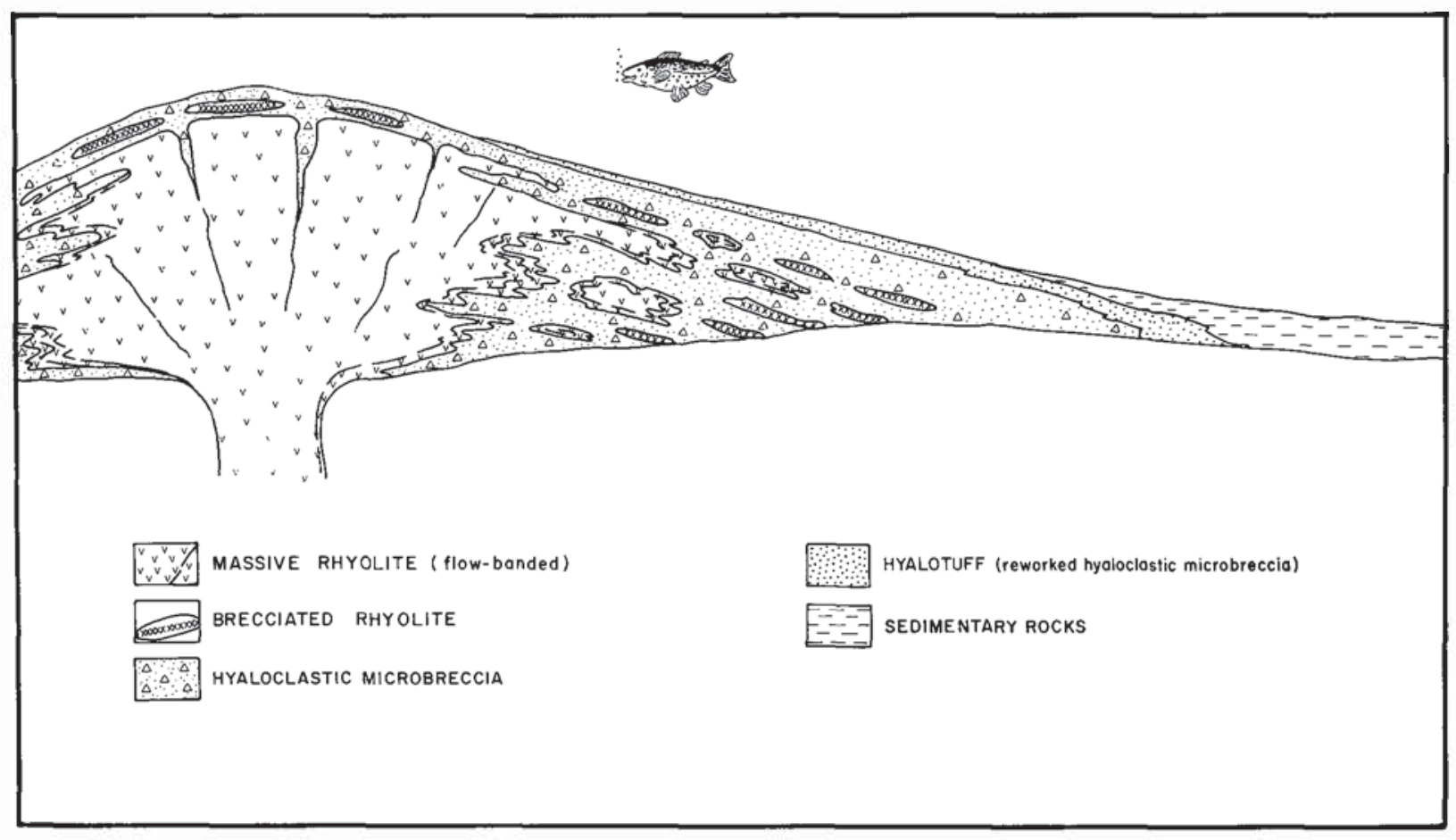

Fig. 7. Rhyolite textural/depositional facies in a subaqueous environment (after McCutcheon, 1990). 
and some mafic volcanic rocks, are transected by a penetrative cleavage axial planar to folds and parallel to regional strike. Major faults, such as the Blue Bell fault (Fig. 2), also trend NE-SW to NNE-SSW. Numerous late-stage faults, trending ENE-WSW and ESE-WNW of fset the various units in the Riley Brook area (Fig. 2).

Metamorphic grade in the Tobique Group is subgreenschist, and characterized in basaltic rocks by the assemblage albite \pm chlorite \pm calcite \pm epidote \pm titanite \pm pumpellyite \pm prehnite. Prehnite pseudomorphs after zeolites are present as vesicle-fillings in some scoriaceous basaltic tuffs; actinolite has been noted, but is quite rare. Sedimentary and felsic volcanic rocks normally contain only sericite and chlorite as secondary minerals.

\section{Geochemistry}

Whole rock and trace element analyses were carried out on 89 samples of mafic and felsic rocks. Although rocks that had clearly undergone alteration, or that contained amygdules or carbonate veinlets were not analyzed, the effect of secondary processes is evident in about $10 \%$ of the samples, manifested in anomalous alkali ratios in some felsic rocks, and in high ( $>5 \%)$ L.O.I. in some mafic rocks. Major elements and $\mathrm{Rb}, \mathrm{Sr}, \mathrm{Ba}, \mathrm{Ga}, \mathrm{Y}, \mathrm{Zr}, \mathrm{Nb}, \mathrm{Zn}, \mathrm{Cu}, \mathrm{Ni}$ and $\mathrm{Cr}$ were determined by X-ray fluorescence at St. Mary's University, Halifax, Nova Scotia. Major oxide determinations were carried out on fused glass discs whereas trace elements were done on pressed powder pellets. Analytical precision, as determined from replicate analyses, is better than $5 \%$ for the major oxides and 5 to $10 \%$ for trace elements. Rare-earth elements (REE) and Sc, Co, Hf, Th, and Ta were analyzed by the instrumental neutron activation technique, also at St. Mary's University. Complete data sets, including calibration values determined on international standards, are available from the author.

The chemistry of volcanic rocks in the Riley Brook area is typical of Siluro-Devonian volcanic rocks elsewhere in northern and western New Brunswick (Dostal et al., 1989). Tables 1 and 2 present average major and trace element compositions of felsic and mafic volcanic rocks, respectively; the volcanic rock compositions show a bimodal distribution with very few intermediate values. Rhyolites in the Riley Brook area, though predominantly subalkaline, show a pattern of increasing alkalinity from east to west (i.e., River Dee suite to Blue Mountains suite), characterized by increasing $\mathrm{Y}, \mathrm{Nb}, \mathrm{Zr}, \mathrm{Ga}, \mathrm{Hf}, \mathrm{Ta}$, and $\mathrm{Nb} \backslash \mathrm{Y}$ and $\mathrm{Zr} \backslash \mathrm{TiO}_{2}$ ratios (Table 1). The Blue Mountains rhyolites are the most alkaline and plot in the peralkaline field on the $\mathrm{Nb} \backslash \mathrm{Y}$ versus $\mathrm{ZrTiO}_{2}$ diagram of Winchester and Floyd (1977). The Black Mountains and Blue Mountains rhyolites are both peralkaline according to the classification of Leat et al. (1986), based on average $\mathrm{Zr}$ contents of 653 and $726 \mathrm{ppm}$, respectively. Similar $\mathrm{Zr}$ values are obtained from the assumed subvolcanic counterparts of these suites (i.e., the "felsic intrusions" in Table 1). An average REE profile of felsic volcanic rocks (Fig. 8a), compared with mafic volcanic rocks (Fig. 8b), illustrates a somewhat more fractionated pattem $(\mathrm{La} / \mathrm{Lu}=46$ versus 36) and higher absolute abundances (avg. $\Sigma$ REE $=302$ ppm versus $95 \mathrm{ppm}$ ), as well as a prominent negative Eu anomaly. Basalts plot in the subalkaline field on the $\mathrm{Nb} / \mathrm{Y}$ versus $\mathrm{Zr} / \mathrm{TiO}_{2}$ diagram of Winchester and Floyd (1977), and their trace element signatures (Table 2) and REE profiles (Fig. 8b) resemble those of continental tholeiites (e.g., Dupuy and Dostal, 1984) and calc-alkali basalts (Pearce, 1982). However, compared with calc-alkali or volcanic-arc basalts, basalts of the Riley Brook area are enriched in high-fieldstrength elements (e.g., $\mathrm{Ti}, \mathrm{P}, \mathrm{Zr}$ ) and show $\mathrm{Fe}$ and $\mathrm{Ti}$ enrichment trends (Dostal et al., 1989) and are therefore best characterized as continental tholeiites. On discrimination diagrams used to infer tectonic setting, both rhyolites (Fig. 9a) and basalts (Fig. 9b) plot in the within-plate field.

\section{The Sewell Brook Deposit}

\section{Geology}

Comprehensive study of the Sewell Brook sulphide deposit has not as yet been undertaken; however, some statements regarding the major features of the local geology and the sulphide body can be made. Although the regional structural trend is NE-SW, the strata in the vicinity of the deposit strike N-S to NNW-SSE and dip moderately to steeply west (Figs. $10,11,12$ ). The stratigraphy at Sewell Brook consists of an interbedded and interfingering succession of sedimentary and felsic volcanic rocks, with minor mafic volcanic rocks. Sedimentary rocks are mainly green to grey, massive to thinbedded or laminated siltstones and fine- to medium-grained sandstones, with minor intercalated beds of volcaniclastic sedimentary rocks. Felsic volcanic rocks consist of grey to green, massive, locally porphyritic and typically perlitic or devitrified rhyolites. Irregular patterns of devitrification and alteration locally produce mottled, pseudo-fragmental textures (Fig. 13a). The rhyolites are commonly transitional to hyaloclastic microbreccia (Fig. 13b,c), through a zone of in situ brecciation, so that mantles or aprons of microbreccia typically envelop units of massive rhyolite. Microbreccia units locally include large clasts or small lobes of massive to brecciated, glassy rhyolite; microbreccia is normally overlain by a layer of reworked hyaloclastic material up to $2 \mathrm{~m}$ thick.

In the mineralized zones at Sewell Brook, massive sulphides horizons are apparently stratabound and generally structureless, though some banded massive sulphide has been reported (D. Burton, personal communication, 1991). In places, hyaloclastic microbreccia in the footwall of the deposit is replaced by sulphides so that the stratigraphically lower parts of the deposit locally display replacement textures (Fig. 13d). Very high grades have been obtained from several drill intercepts (Table 3 ), including $41 \%$ combined $\mathrm{Zn}+\mathrm{Pb}$ over $5.7 \mathrm{~m}$ in hole $10,36 \% \mathrm{Zn}+\mathrm{Pb}$ over $5 \mathrm{~m}$ in hole 11 , and $33 \% \mathrm{Zn}+\mathrm{Pb}$ over $10 \mathrm{~m}$ in hole 10D. The main sulphide lens is typically rich in $\mathrm{Zn}$ compared to $\mathrm{Pb}$ : the average $\mathrm{ZnVPb}$ ratio for all drill intercepts listed in Table 3 is 
Table 1. Average major and trace element compositions of felsic volcanic rocks from Riley Brook area.

\begin{tabular}{|c|c|c|c|c|c|}
\hline & \multicolumn{4}{|c|}{ FELSIC VOLCANIC ROCKS } & \multirow{2}{*}{$\begin{array}{c}\text { FELSIC } \\
\text { INTRUSIONS }\end{array}$} \\
\hline & RIVER DEE & GULQUAC MTNS. & BLACK MTNS. & BLUE MTNS. & \\
\hline $\mathrm{n}$ & 6 & 6 & 10 & 10 & 5 \\
\hline $\mathrm{SiO}_{2}$ & 75.61 & 73.86 & 73.42 & 75.23 & 68.17 \\
\hline $\mathrm{TiO}_{2}$ & 0.19 & 0.24 & 0.30 & 0.20 & 0.80 \\
\hline $\mathrm{Al}_{2} \mathrm{O}_{3}$ & 12.57 & 13.40 & 12.64 & 11.74 & 13.73 \\
\hline $\mathrm{Fe}_{2} \mathrm{O}_{3}$ & 2.68 & 2.42 & 3.74 & 3.02 & 5.78 \\
\hline $\mathrm{MnO}$ & 0.05 & 0.05 & 0.06 & 0.04 & 0.10 \\
\hline $\mathrm{MgO}$ & 1.17 & 0.81 & 1.10 & 0.74 & 1.62 \\
\hline $\mathrm{CaO}$ & 0.05 & 0.67 & 0.47 & 0.32 & 1.66 \\
\hline $\mathrm{Na}_{2} \mathrm{O}$ & 3.57 & 3.94 & 4.06 & 3.06 & 4.31 \\
\hline $\mathrm{K}_{2} \mathrm{O}$ & 4.02 & 4.52 & 4.13 & 5.57 & 3.61 \\
\hline $\mathrm{P}_{2} \mathrm{O}_{5}$ & 0.09 & 0.10 & 0.08 & 0.08 & 0.22 \\
\hline $\mathbf{R b}$ & 142 & 143 & 122 & 212 & 122 \\
\hline $\mathrm{Sr}$ & 61 & 81 & 47 & 43 & 102 \\
\hline $\mathrm{Ba}$ & 483 & 535 & 465 & 243 & 530 \\
\hline Sc & $3.4^{* *}$ & $4.8^{* *}$ & $8.0^{* *}$ & $0.3^{* *}$ & $11.7^{*}$ \\
\hline $\mathrm{Cr}$ & 35 & 31 & 31 & 29 & 30 \\
\hline Co & $4.3^{* *}$ & $0.9^{* *}$ & $0.7^{* *}$ & $0.2^{* *}$ & $8.4^{*}$ \\
\hline $\mathrm{Ni}$ & 9 & 7 & 6 & 5 & 6 \\
\hline $\mathrm{Cu}$ & 10 & 14 & 11 & 15 & 16 \\
\hline $\mathrm{Zn}$ & 43 & 75 & 62 & 71 & 73 \\
\hline $\mathrm{Y}$ & 52 & 51 & 82 & 83 & 56 \\
\hline $\mathrm{Zr}$ & 274 & 329 & 653 & 721 & 481 \\
\hline $\mathrm{Nb}$ & 25 & 19 & 33 & 47 & 27 \\
\hline $\mathrm{Ga}$ & 16 & 17 & 19 & 21 & 19 \\
\hline Hf & $8.4^{* *}$ & $9.3^{* *}$ & $18.1^{* *}$ & $20.8^{* *}$ & $10.4^{*}$ \\
\hline Th & 21.9 & $26.8^{* *}$ & $24.5^{* *}$ & $23.4^{* *}$ & $17.0^{*}$ \\
\hline $\mathrm{Ta}$ & 2.00 & $1.63^{* *}$ & $2.22^{* *}$ & $3.29^{* *}$ & $1.91^{*}$ \\
\hline $\mathrm{n}$ & 2 & 2 & 2 & 2 & 3 \\
\hline $\mathrm{La}$ & 40.45 & 59.70 & 87.35 & 53.10 & 50.70 \\
\hline $\mathrm{Ce}$ & 92.95 & 129.00 & 176.00 & 121.50 & 114.27 \\
\hline Nd & - & 68.00 & 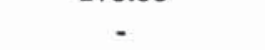 & 101.00 & - \\
\hline $\mathrm{Sm}$ & 11.72 & 11.29 & 19.75 & 15.71 & 12.30 \\
\hline $\mathrm{Eu}$ & 0.87 & 1.23 & 2.67 & 0.19 & 2.11 \\
\hline $\mathrm{Tb}$ & 1.99 & 1.75 & 3.09 & 3.22 & 1.98 \\
\hline $\mathrm{Yb}$ & 6.26 & 5.85 & 10.16 & 10.65 & 6.14 \\
\hline $\mathrm{Lu}$ & 0.97 & 0.93 & 1.64 & 1.70 & 1.02 \\
\hline
\end{tabular}

Major elements recalculated to $100 \%$ on an LOI-free basis.

** - 2 analyses; ${ }^{*}-3$ analyses

3.4 , although in the highest grade sections, the proportion of $\mathrm{Zn}$ is even higher. The sphalerite in most of the $\mathrm{Zn}$-enriched horizons is a honey-yellow or reddish colour, but in some cases the sulphide horizon is black. The significance of these sphalerite colour variations remains unclear; however, the honey-yellow variety is more $\mathrm{Zn}$-rich. Copper-rich zones are locally present stratigraphically below the $\mathrm{Zn}-\mathrm{Pb}$ horizon; these zones are variable in grade and thickness. The highest grade of $\mathrm{Cu}$ is $17.4 \%$ over $1.5 \mathrm{~m}$ in hole 10 ; the widest zone of Cu-enrichment is a $10 \mathrm{~m}$ section of discordant stringer- 
Table 2. Average major and trace element compositions of mafic volcanic rocks from Riley Brook area.

\begin{tabular}{|c|c|c|c|c|c|}
\hline & \multicolumn{4}{|c|}{ MAFIC VOLCANIC ROCKS } & \multirow[b]{2}{*}{$\begin{array}{c}\text { MAFIC } \\
\text { INTRUSIONS }\end{array}$} \\
\hline & \multicolumn{2}{|c|}{ RIVER DEE } & $\begin{array}{c}\text { BLACK } \\
\text { MOUNTAINS }\end{array}$ & $\begin{array}{c}\text { BLUE } \\
\text { MOUNTAINS }\end{array}$ & \\
\hline $\mathrm{n}$ & 3 & 3 & 7 & 16 & 23 \\
\hline $\mathrm{SiO}_{2}$ & 51.11 & 58.12 & 51.70 & 49.97 & 50.92 \\
\hline $\mathrm{TiO}_{2}$ & 1.50 & 1.91 & 1.73 & 1.95 & 1.75 \\
\hline $\mathrm{Al}_{2} \mathrm{O}_{3}$ & 16.60 & 14.39 & 16.43 & 16.37 & 16.25 \\
\hline $\mathrm{Fe}_{2} \mathrm{O}_{3}$ & 9.43 & 11.31 & 9.41 & 10.20 & 9.87 \\
\hline $\mathrm{MnO}$ & 0.19 & 0.23 & 0.29 & 0.17 & 0.17 \\
\hline $\mathrm{MgO}$ & 7.42 & 3.06 & 7.61 & 7.06 & 7.54 \\
\hline $\mathrm{CaO}$ & 8.73 & 4.91 & 7.81 & 9.59 & 8.87 \\
\hline $\mathrm{Na}_{2} \mathrm{O}$ & 3.68 & 3.76 & 3.85 & 3.55 & 3.34 \\
\hline $\mathrm{K}_{2} \mathrm{O}$ & 1.09 & 1.58 & 0.99 & 0.83 & 1.00 \\
\hline $\mathrm{P}_{2} \mathrm{O}_{5}$ & 0.23 & 0.73 & 0.16 & 0.32 & 0.31 \\
\hline$[\mathrm{Mg}]$ & .61 & .35 & .62 & .58 & .60 \\
\hline $\mathrm{Rb}$ & 40 & 49 & 28 & 26 & 30 \\
\hline $\mathrm{Sr}$ & 252 & 144 & 280 & 244 & 349 \\
\hline $\mathrm{Ba}$ & 140 & 294 & 243 & 164 & 218 \\
\hline Sc & - & $34.5^{* *}$ & $3.12^{* *}$ & $31.6^{*}$ & $28.4^{* * *}$ \\
\hline V & 247 & 123 & 241 & 265 & 234 \\
\hline $\mathrm{Cr}$ & 247 & 34 & 272 & 212 & 195 \\
\hline Co & - & $11.9^{* * *}$ & $3.5^{* *}$ & $12.0^{*}$ & $32.1^{* * *}$ \\
\hline $\mathrm{Ni}$ & 80 & 18 & 84 & 80 & 87 \\
\hline $\mathrm{Cu}$ & 30 & 6 & 30 & 20 & 26 \\
\hline $\mathrm{Zn}$ & 86 & 118 & 85 & 105 & 95 \\
\hline$Y$ & 25 & 62 & 29 & 29 & 29 \\
\hline $\mathrm{Zr}$ & 133 & 546 & 166 & 161 & 159 \\
\hline $\mathrm{Nb}$ & 6 & 19 & 8 & 8 & 7 \\
\hline $\mathrm{Ga}$ & 15 & 19 & 17 & 17 & 17 \\
\hline Hf & - & $14.3^{* * *}$ & $40.3^{* *}$ & $29.2^{*}$ & $4.75^{* * *}$ \\
\hline Th & - & $11.0^{* * *}$ & $2.7^{* *}$ & $1.9^{*}$ & $5.71^{* * *}$ \\
\hline $\mathrm{Ta}$ & - & $1.32^{* * *}$ & $0.52^{* *}$ & $0.44^{*}$ & $0.72 * * *$ \\
\hline $\mathbf{n}$ & - & 1 & 2 & 4 & 1 \\
\hline $\mathrm{La}$ & - & 41.00 & 15.29 & 11.85 & 29.30 \\
\hline $\mathrm{Ce}$ & - & 91.50 & 34.40 & 27.90 & 64.60 \\
\hline $\mathrm{Nd}$ & - & 44.30 & 19.75 & 17.47 & - \\
\hline $\mathrm{Sm}$ & - & 10.70 & 4.91 & 4.43 & 7.37 \\
\hline $\mathrm{Eu}$ & - & 3.05 & 1.63 & 1.57 & 1.97 \\
\hline $\mathrm{Tb}$ & - & 1.91 & 0.95 & 0.87 & 1.17 \\
\hline $\mathrm{Yb}$ & - & 5.38 & 2.70 & 2.57 & 3.30 \\
\hline $\mathrm{Lu}$ & - & 0.83 & 0.41 & 0.41 & 0.54 \\
\hline
\end{tabular}

Major elements recalculated to $100 \%$ on an LOI-free basis. $[\mathrm{Mg}]=\operatorname{mol} . \mathrm{MgO} / \mathrm{MgO}+\mathrm{FeO}_{\mathrm{T}}$

* -4 analyses; ${ }^{* *}-2$ analyses; ${ }^{* * *}-1$ analysis

stockwork ore in hole 1 grading $3.7 \% \mathrm{Cu}$. Significant gold and silver are present in some high-grade $\mathrm{Zn}$-Pb horizons; the best values are found in hole 11 , with $135 \mathrm{~g} \backslash \mathrm{T} \mathrm{Ag}$ and $1.73 \mathrm{~g} \backslash \mathrm{T}$
Au over $5 \mathrm{~m}$. The deposit is close to surface, having been intersected at depths as shallow as $10 \mathrm{~m}$ (Table 3). A second mineralized zone was intersected in one drill hole at some- 

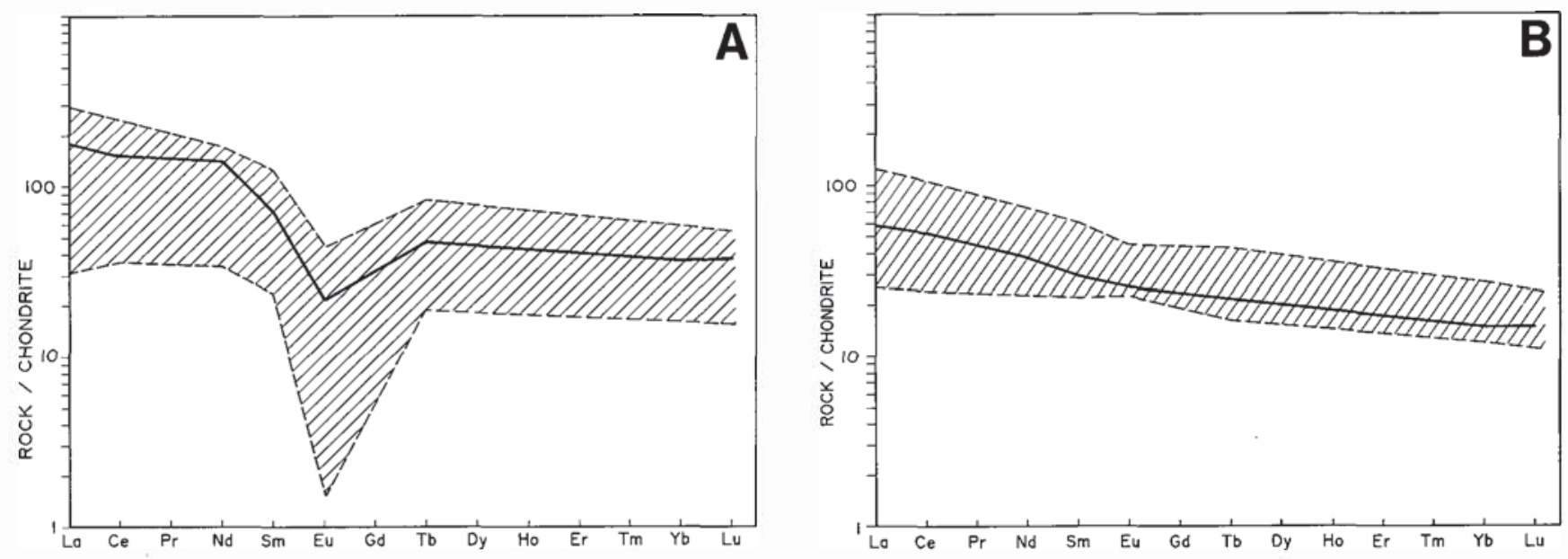

Fig. 8. Average chondrite-normalized REE profiles (solid lines) and range of values (cross-hatched) in volcanic rocks of the Riley Brook area. (A) felsic volcanic rocks $(n=8)$; (B) mafic volcanic rocks $(n=8)$. Normalizing values after Frey et al. (1968).
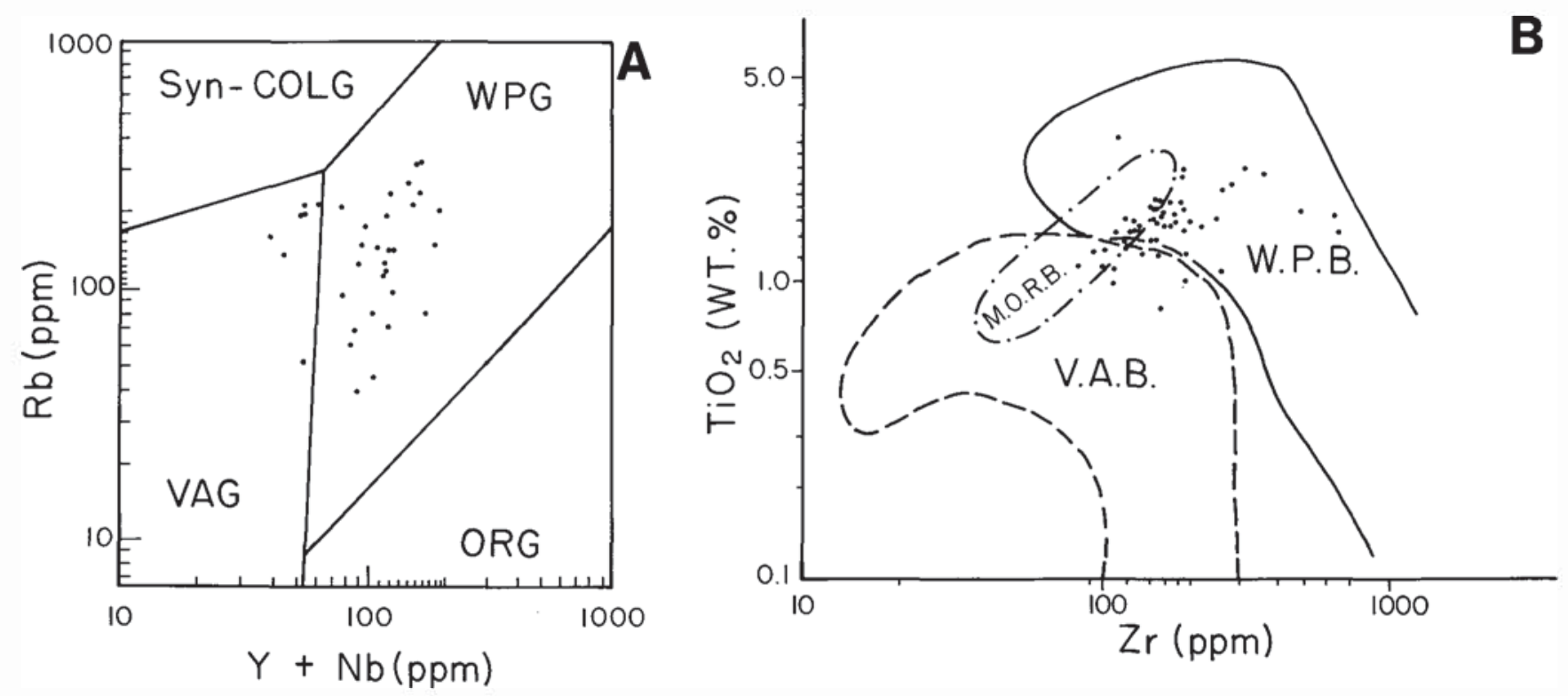

Fig. 9. Tectonic discrimination diagrams for volcanic rocks of the Riley Brook area. (A) Rb versus $\mathrm{Y}+\mathrm{Nb}$ discrimination diagram for granites (Pearce et al., 1984) applied to rhyolites of the Riley Brook area. WPG - within-plate granites; Syn-COLG - syncollision granites; VAG - volcanic-arc granites; ORG - ocean-ridge granites. (B) $\mathrm{TiO}_{2}$ versus $\mathrm{Zr}$ discrimination diagram (Pearce, 1982) for basalts of the Riley Brook area. WPB - within-plate basalt; MORB - mid-ocean ridge basalt; VAB - volcanic-arc basalt.

what greater depth; the potential of this zone remains untested to date.

A possibly significant feature of the local geology is the interpreted fault in cross-sections A, B and C (Fig. 12). The surface trace of this fault, if extended to the north, coincides with a strong topographic lineament formed by a gully between two steep hills (Fig. 10). Although definitive evidence of syn-volcanic growth faulting is lacking, there is reason to view this structure as a possible focused channelway for mineralizing fluids: (1) on cross-section B (Fig. 12), the massive sulphide zone changes markedly in width across this fault, and a wide section of $\mathrm{Cu}$-rich stringer-stockwork ore is present where one drill hole intersects it; and (2) on crosssection C (Fig. 12), the sulphide lens as shown pinches out east of the fault; however, this interpretation is not verified by drilling, and the sulphide body may as easily terminate against the fault. Several linear features (plotted on Fig. 10) are parallel or sub-parallel to this "Sewell Brook lineament" and should represent good exploration targets.

Sericite and chlorite alteration are extensive in the footwall to the main sulphide zone and silicification is commonly present within units of siltstone and massive rhyolite, spatially associated with pyritic or low-grade $\mathrm{Zn}$ - $\mathrm{Pb}$-mineralized horizons. Silicified siltstone commonly overlies massive sulphides of the main sulphide zone, and also locally overlies microbreccia or reworked microbreccia associated with the main sulphide zone. In the absence of detailed logging of all core and systematic petrographic and chemical investigations, the three-dimensional distribution of the various types of alteration is unknown. 


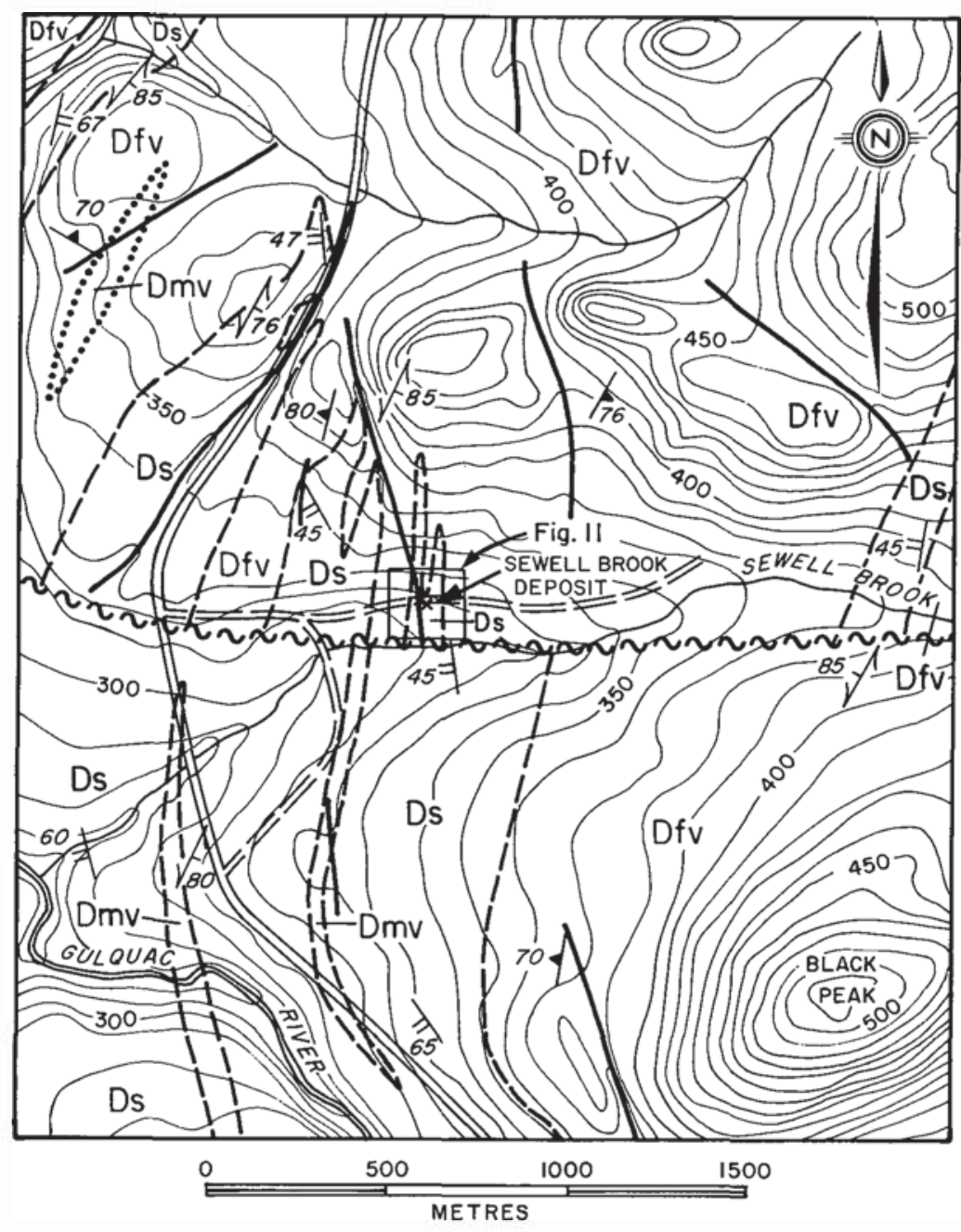

\section{LEGEND}

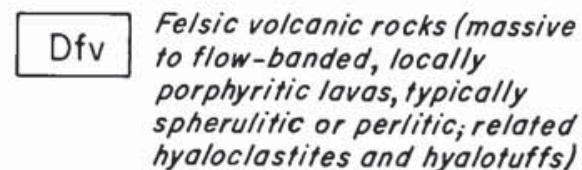

Dmv Mafic volcanic rocks

Ds sedimentary rocks

$\overline{=}=$ Roods

น น น Fault

-........ Geological contact

(approximate, assumed)

II Bedding

15 Cleavage

70 Flow-banding in rhyolite

Topographic lineament

- 450- Topographic contour (metres)

Fig. 10. Local geology of the Sewell Brook area.

\section{Comparison with Kuroko Deposits}

The Sewell Brook deposit resembles a typical Kuroko VMS deposit (Ohmoto and Skinner, 1983; Lambert and Sato, 1974) in several respects; for example: (1) there is a spatial association of sulphide zones with brecciated felsic volcanic rocks situated adjacent to massive rhyolite bodies; (2) there is no magnetite or pyrrhotite associated with the Sewell Brook deposit; (3) stockwork mineralization underlies the main sulphide zone; (4) metal zoning is similar to both Bathurst-type and Kuroko-type deposits; (5) silicic, sericitic and chloritic alteration is widespread in rocks near the deposit, especially in the footwall; and (6) significant enrichment in $\mathrm{K}$ (Wilson, 1988) and in $\mathrm{Mg}$ has occurred. As shown in Table 4, a 20- to 30-fold increase in $\mathrm{Mg}$ with respect to $\mathrm{Fe}$ is evident in chlorites from hyaloclastic microbreccia in the footwall alteration zone, compared with chlorites in relatively fresh rhyolites. Chlorites in Bathurst-camp deposits, in contrast, are always Fe-rich (McCutcheon, 1990). In some ways the Sewell Brook deposit differs from the Kuroko model: the lack of barite and anhydrite, and the absence of a ferruginous chert layer capping the deposit are the most obvious examples. Also, $\mathrm{Zn}$-rich as well as $\mathrm{Cu}$-rich stockwork zones are present. Clastic ore textures such as those characterizing classic Kuroko deposits are apparently not developed; however, some transported ore fragments have been noted (D. Burton, personal communication, 1991).

\section{Tectonic Setting and Environment of Deposition}

Dostal et al. (1989) interpreted geochemical data to suggest a within-plate, extensional regime for Tobique Zone volcanism. In contrast, McCutcheon and Bevier (1990), while concurring that the geochemical data support a within-plate setting, point out that volcanism took place during a period of dominant compression associated with accretion of the Avalon Terrane to the North American craton and maintain that there is no $a$ priori reason that the tectonic setting must be an extensional one. Nevertheless, several studies have indicated that extension and compression are not mutually exclusive within collisional orogens; for example, diverse mechanisms have been proposed to explain local or short-lived extensional tectonism and associated plutonism or volcanism within dominantly compressional regimes in the southern Appala- 


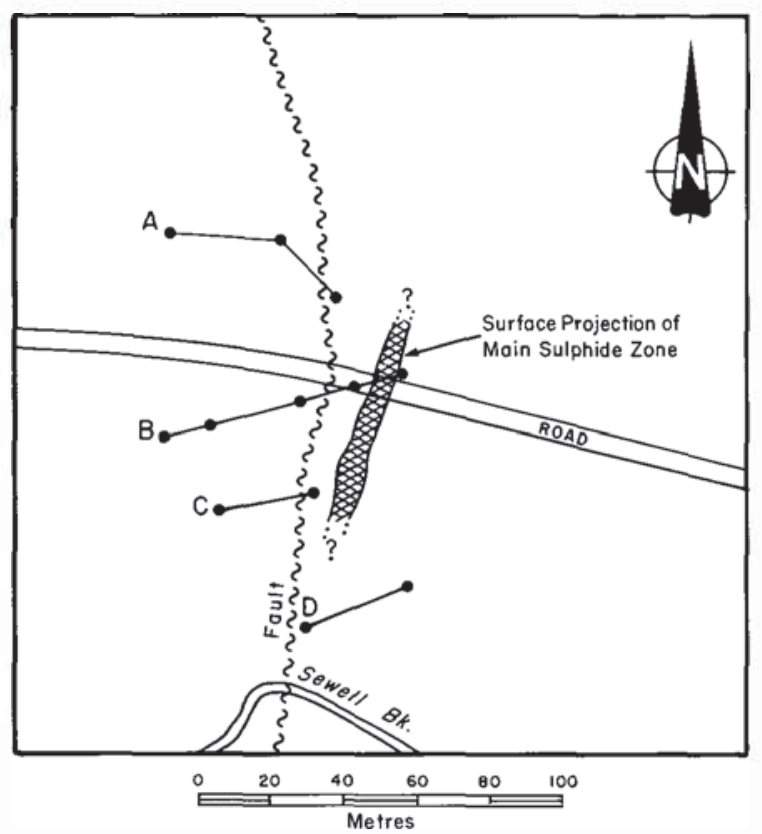

Fig. 11. Location of cross-sections A to D (Fig. 12), and surface projection of main sulphide lens. chians (Sacks and Secor, 1990a), Turkey (Pearce et al., 1990) and the Himalayas (England and Houseman, 1989). Crustal extension, furthermore, would be favoured where the convergence is oblique rather than orthogonal, or where the convergent margins are irregular. In fact, numerous workers have presented evidence that supports oblique convergence of North America and Avalonia during the mid- to late Paleozoic, e.g., Soper and Hutton (1984), Sacks and Secor (1990b), van der Pluijm and van Staal (1988), Blewett and Pickering (1988), and Dostal et al. (1989). Thus, it appears that emplacement of the Tobique Zone volcanic rocks in a submarine environment can be related to subsidence within a local extensional basin formed during oblique transpression.

The water depth at the time of formation of the Sewell Brook deposit can be determined indirectly from the sedimentary rocks underlying the Riley Brook area. As discussed earlier, fossils, bedforms, etc., constrain the depth range of the Tobique Group to between 100 and $200 \mathrm{~m}$; this range appears to be consistent throughout the Tobique Group, unless dramatic variations in water depth existed over short distances. This shallow depth stands in sharp contrast to depths commonly reported for other sites of volcanic-related seafloor mineralization, such as Japan (Guber and Merrill,

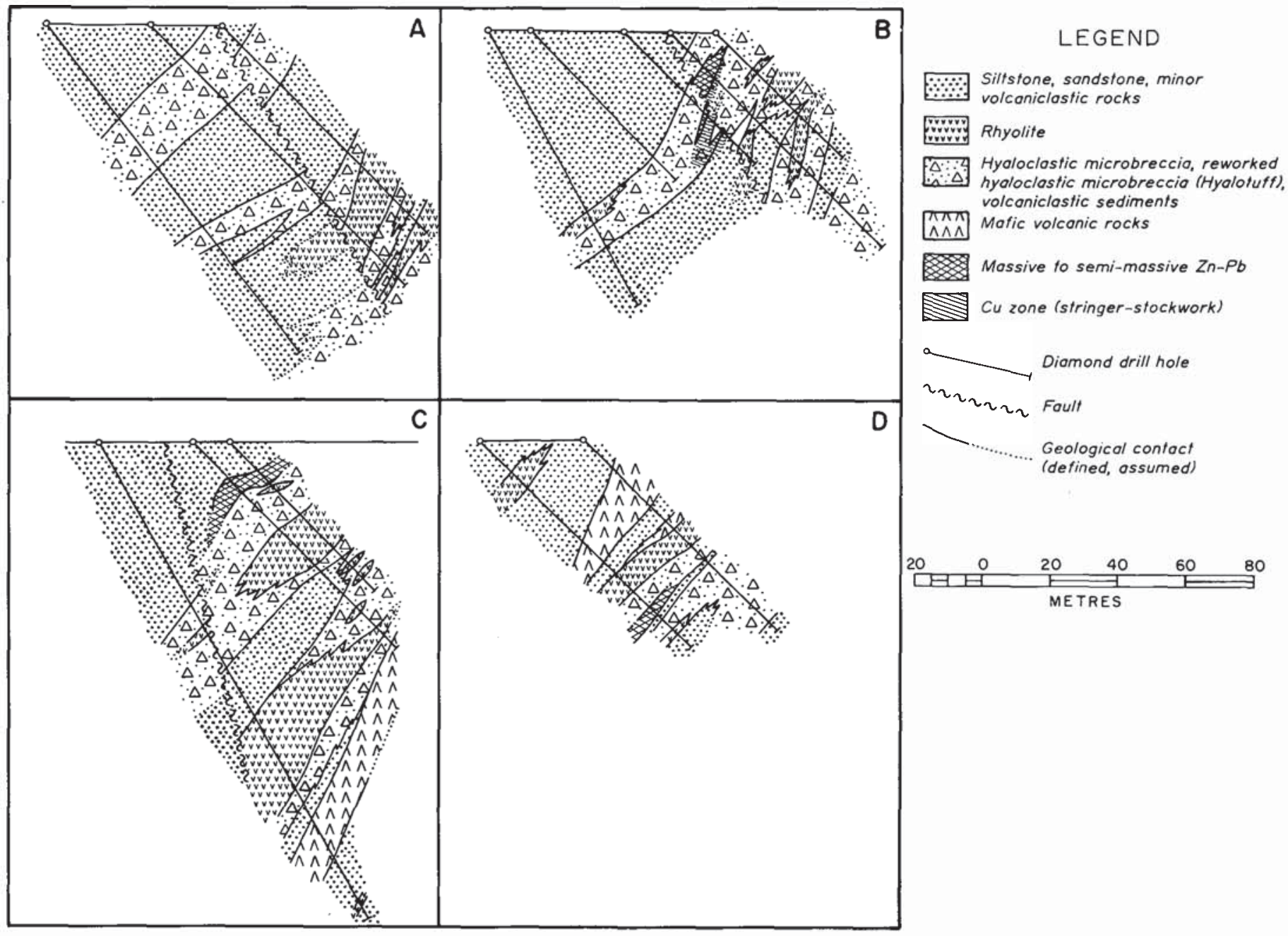

Fig. 12. Cross-sections showing simplified geology of the Sewell Brook deposit. 

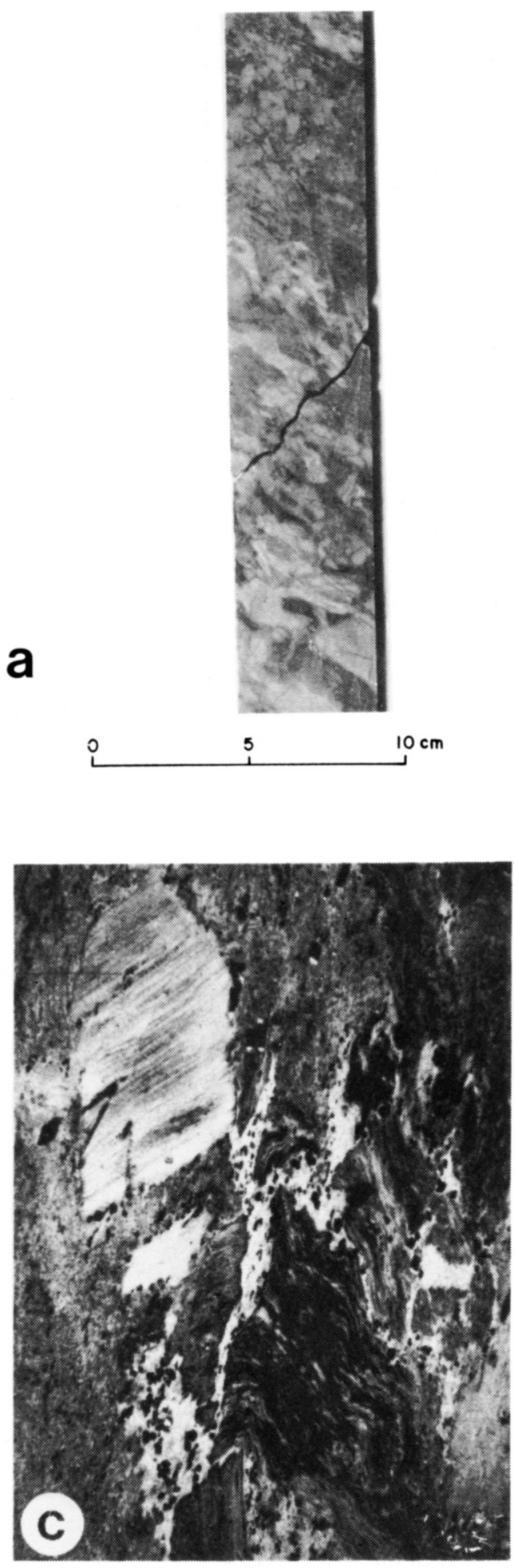

i $2 \mathrm{~mm}$
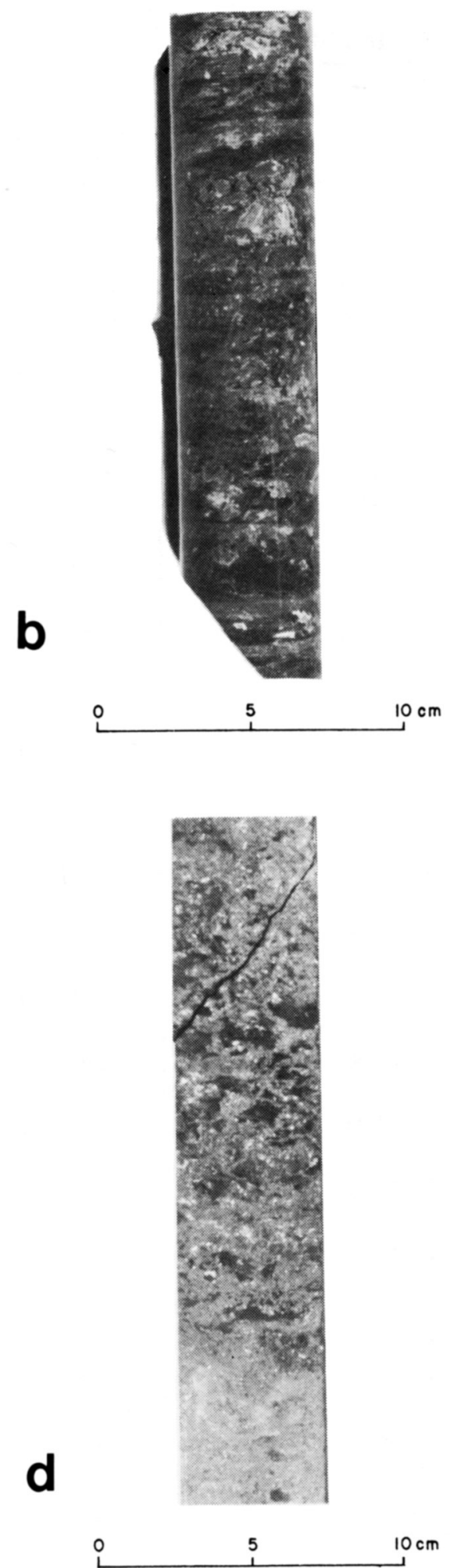

Fig. 13. Representative lithotypes from Sewell Brook drill core. (a) Rhyolite showing mottled or patchy style of devitrification producing apparent fragmental texture (cf. Fig. 5). (b) Typical hyaloclastic microbreccia (cf. Fig. 6a). (c) Photomicrograph of strongly altered hyaloclastic microbreccia from footwall of main sulphide zone; p.p. light. (d) $\mathrm{Zn}$-Pb-rich sulphide zone; sulphides are replacing chloritized hyaloclastic microbreccia.

1983; Cathles et al., 1983), the Red Sea (Shanks and Bischoff, 1980), and other seafloor ridges worldwide (Von
Damm, 1990). Moreover, Cathles et al. (1983) assert that depths in excess of $2000 \mathrm{~m}$ are necessary for formation of $\mathrm{Cu}$ 
Table 3. Significant drill intercepts.

\begin{tabular}{|c|c|c|c|c|c|c|c|c|}
\hline \multirow[b]{2}{*}{ Hole No. } & \multicolumn{2}{|c|}{ INTERVAL(m.) } & \multirow{2}{*}{$\begin{array}{l}\text { Core } \\
\text { Length } \\
(\mathrm{m} .)\end{array}$} & \multirow[b]{2}{*}{$\mathrm{Cu} \%$} & \multirow[b]{2}{*}{$\mathrm{Pb} \%$} & \multirow[b]{2}{*}{$\mathrm{Zn} \%$} & \multirow[b]{2}{*}{$\mathrm{Ag} \mathrm{g} / \mathrm{t}$} & \multirow[b]{2}{*}{ Au g/t } \\
\hline & From & To & & & & & & \\
\hline \multirow{3}{*}{1} & 28.35 & 29.88 & 1.52 & - & 3.10 & 5.96 & 51.60 & - \\
\hline & 32.62 & 34.45 & 1.83 & - & 3.80 & 8.20 & 46.49 & - \\
\hline & 34.45 & 44.51 & 10.06 & 3.72 & - & - & - & - \\
\hline 2 & 68.75 & 73.17 & 4.42 & - & 2.61 & 10.66 & 30.05 & - \\
\hline \multirow[t]{3}{*}{10} & 12.58 & 18.29 & 5.72 & 0.50 & 11.95 & 29.02 & 78.53 & 0.77 \\
\hline & 18.29 & 19.82 & 1.52 & 17.44 & 0.38 & 7.08 & 45.93 & 0.57 \\
\hline & 19.82 & 25.61 & 5.79 & 0.07 & 1.45 & 6.62 & 19.56 & 0.43 \\
\hline 11 & 14.33 & 19.36 & 5.03 & 0.37 & 10.28 & 25.81 & 134.95 & 1.73 \\
\hline $2 \mathrm{D}$ & 15.20 & 17.50 & 2.30 & 0.35 & 7.63 & 12.40 & 121.45 & 1.60 \\
\hline \multirow[t]{2}{*}{$3 \mathrm{D}$} & 13.11 & 15.70 & 2.59 & 2.24 & 3.39 & 20.50 & 45.79 & 0.58 \\
\hline & 30.30 & 32.00 & 1.70 & 0.09 & 4.96 & 10.06 & 39.04 & 0.38 \\
\hline $4 \mathrm{D}$ & 13.45 & 23.40 & 9.95 & 0.47 & 4.25 & 20.60 & 82.98 & 0.69 \\
\hline $5 \mathrm{D}$ & 10.75 & 20.63 & 9.88 & 0.34 & 2.99 & 8.06 & 66.99 & 0.51 \\
\hline $6 \mathrm{D}$ & 30.70 & 33.55 & 2.85 & 0.34 & 5.17 & 17.05 & 74.72 & 0.93 \\
\hline $8 D$ & 20.45 & 32.00 & 11.55 & 0.50 & 3.07 & 14.85 & 62.82 & 0.73 \\
\hline 9D & 20.50 & 25.20 & 4.70 & 0.12 & 3.60 & 7.32 & 72.12 & 0.77 \\
\hline 10D & 23.08 & 32.86 & 9.78 & 1.04 & 4.58 & 28.08 & 52.39 & 0.69 \\
\hline 13D & 21.87 & 27.92 & 6.05 & 0.09 & 1.71 & 6.45 & 44.31 & 0.43 \\
\hline 17D & 43.10 & 47.88 & 4.78 & 0.49 & 4.73 & 21.34 & 56.19 & 0.48 \\
\hline $18 \mathrm{D}$ & 33.83 & 37.41 & 3.58 & 0.45 & 5.37 & 23.42 & 42.14 & 0.65 \\
\hline $20 \mathrm{D}$ & 38.30 & 47.65 & 9.35 & 1.40 & 2.26 & 14.50 & 31.18 & 0.50 \\
\hline
\end{tabular}

+ Zn VMS deposits in order to prevent boiling and consequent formation of a vein-type deposit. Nevertheless, some sulphide deposits appear to form at much shallower depths. Beeson (1990), reporting on the geology of Broken Hill-type $\mathrm{Pb}-\mathrm{Zn}$ deposits in Australia, Sweden, Canada and elsewhere, presents evidence of very shallow-water deposition. Extensional tectonic settings, which prevailed during the formation of these deposits (Beeson, 1990), therefore do not necessarily demand deep, subsiding troughs. At the water depths indicated in the Riley Brook area, it seems clear that in order to prevent boiling and allow for the formation of a tabularstratiform deposit rather than a lode-vein deposit, low temperature $\left(<200^{\circ} \mathrm{C}\right)$ hydrothermal solutions are required (Ridge, 1973). Insufficient data are currently available to constrain other factors involved in the genesis of the Sewell Brook deposit; in any case, such a discussion is beyond the scope of this paper. 
Table 4. Chlorite analyses from Sewell Brook drill core.

\begin{tabular}{||l|c|c|c||}
\hline & $90-11-143^{1}$ & $90-10-84^{2}$ & $90-10-102^{3}$ \\
\hline & & & \\
$\mathrm{n}$ & 3 & 5 & 9 \\
$\mathrm{SiO}_{2}$ & 25.33 & 30.55 & 33.21 \\
$\mathrm{Al}_{2} \mathrm{O}_{3}$ & 21.74 & 23.71 & 22.34 \\
$\mathrm{TiO}_{2}$ & 0.05 & 0.13 & 0.12 \\
$\mathrm{FeO}$ & 49.75 & 24.12 & 18.59 \\
$\mathrm{MnO}$ & 0.89 & 0.95 & 1.14 \\
$\mathrm{MgO}$ & 2.09 & 20.26 & 23.81 \\
$\mathrm{CaO}$ & 0.03 & 0.04 & 0.05 \\
$\mathrm{Na}$ & 0.05 & 0.06 & 0.01 \\
$\mathrm{~K}_{2} \mathrm{O}$ & 0.08 & 0.09 & 0.73 \\
$\mathrm{Fe} / \mathrm{Mg}$ & 23.8 & 1.2 & 0.8 \\
& & & \\
\hline
\end{tabular}

Oxides are recalculated to $100 \%$

1 chlorites from relatively fresh rhyolites; 2,3 - chlorites from highly altered hyaloclastic microbreccia in footwall of main sulfide zone.

\section{Discussion and Conclusions}

Field and petrographic evidence favors a subaqueous environment of deposition for most volcanic and sedimentary rocks in the Riley Brook area. This evidence consists of: (1) rhyolite facies associations typical of subaqueous flows (e.g., de Rosen-Spence et al., 1980), characterized by a zonation from a non glassy core, to a glassy (perlitic/spherulitic) border zone that is enveloped by hyaloclastic microbreccia; (2) conformable relationships between hyaloclastic microbreccias, volcaniclastic sedimentary rocks interpreted as reworked microbreccias, and marine siltstones and sandstones; and (3) pillow structures and hyaloclastic textures in mafic volcanic units.

Recognition of texturally modified glassy rhyolites and spatially-related fragmental rocks as subaqueous facies (felsic lavas and hyaloclastites, respectively) rather than as subaerial deposits, has important economic implications. It is generally recognized that volcanogenic massive sulphide deposits originate from seafloor hydrothermal activity (e.g., Lydon, 1988; Franklin et al., 1981; Soloman and Walshe, 1979). To the explorationist, the exclusive occurrence of these deposits on the seafloor therefore highlights the importance of correctly interpreting depositional environments in volcano-sedimentary sequences.

In addition to aiding in the interpretation of depositional setting, the textures described herein also tend to enhance the viability of felsic volcanic rocks as sources of metals or as hosts to mineralization; moreover, the process of textural modification, manifested in pseudo-fragmental textures, may indicate the proximity of hydrothermal activity. In the Riley Brook area, post-depositional phenomena such as perlitic fracturing and devitrification have increased the permeability of large volumes of rhyolite to circulating hydrothermal fluids, thereby creating a potential source of metals for mobilization by those fluids. The porosity of the hyaloclastic microbreccias associated with altered glassy lavas similarly allows them to be readily leached and altered, and at Sewell Brook has locally permitted their replacement by sulphide minerals. Pseudo-fragmental textures result from irregular or incomplete devitrification combined with alteration of glassy lava. Allen (1988) has suggested that extensive development of pseudo-fragmental textures is favored by pervasive hydrothermal alteration, although it seems possible that in some cases textural modification, similar in style but differing in degree, can result from interaction of hot lava with seawater. In the Riley Brook area, the local spatial relationship of altered perlitic and devitrified rhyolites with base metal occurrences suggests that several hydrothermal centres may have existed.

\section{ACKNOWLEDgements}

The author wishes to thank Don Burton of NovaGold Resources Limited for access to drill core and drill logs. The manuscript has benefitted greatly by critical comment and advice from L.R. Fyffe, S.R. McCutcheon, and an anonymous referee. Microprobe work was carried out by D. Rae at the SEM facility, University of New Brunswick. Photographic services were provided by E. Bagnell. G. Johnson drafted the figures and $\mathrm{K}$. Stewart typed the manuscript. Field work was funded by the Canada-New Brunswick Mineral Development Agreement 1984-89. 
Allen, R.L. 1988. False pyroclastic textures in altered silicic lavas, with implications for volcanic-associated mineralization. Economic Geology, 83, pp. 1424-1446.

Anderson, F.D. 1962. Geology of Tobique area, New Brunswick. Geological Survey of Canada, Map 37-1962 (with marginal notes).

Beeson, R. 1990. Broken Hill-type lead-zinc deposits--an overview of their occurrence and geological setting. Transactions of the Institution of Mining and Metallurgy, pp. B163-B175.

Blewett, R.S. and Pickering, K.T. 1988. Sinistral shear during Acadian deformation in north-central Newfoundland, based on transecting cleavage. Journal of Structural Geology, 10. pp. 125-127.

Cathles, M.L., Guber, A.L., Lenagh, T.C., and Dudas, F.O. 1983. Kuroko-type massive sulphide deposits of Japan: products of an aborted island-arc rift. In The Kuroko and Related Volcanogenic Massive Sulphide Deposits. Edited by $\mathrm{H}$. Ohmoto and B.J. Skinner. Economic Geology, Monograph 5, pp. 96-114.

DAvies, J.L. 1979. Geological map of northern New Brunswick. New Brunswick Department of Natural Resources, Mineral Resources Branch, Map NR-3.

De Rosen-Spence, A.F., Provost, G., Dimroth, E., Gochnauer, K., and OwEN, V. 1980. Archean subaqueous felsic flows, Rouyn-Noranda, Quebec, Canada, and their Quaternary equivalents. Precambrian Research, 12, pp. 43-77.

Dostal, J., Wilson, R.A., and Keppie, J.D. 1989. Geochemistry of Siluro-Devonian Tobique volcanic belt in northern and central New Brunswick, Canada: tectonic implications. Canadian Journal of Earth Sciences, 26, pp. 1282-1296.

DupuY, C. and Dostal, J. 1984. Trace element geochemistry of some continental tholeiites. Earth and Planetary Science Letters, 67, pp. 61-69.

England, P. and Houseman, G. 1989. Extension during continental convergence, with application to the Tibetan Plateau. Journal of Geophysical Research, 94, No. B12, pp. 1756117579.

Fisher, R.V. and Schmincke, H.-U. 1984. Pyroclastic Rocks. Springer-Verlag, $472 \mathrm{p}$.

FISKE, R.S. and MATSUDA, T. 1964. Submarine equivalents of ash flows in the Tokiwa Formation, Japan. American Journal of Science, 262, pp. 76-106.

Franklin, J.M., Lydon, J.W., and SANgster, D.F. 1981. Volcanic-associated massive sulphide deposits. Economic Geology, 75th Anniversary Volume, pp. 523-531.

Frey, F.A., Haskin, M.A., Poetz, J., and Haskin, L.A. 1968. Rare earth abundances in some basic rocks. Journal of Geophysical Research, 73, pp. 6085-6098.

FYFFe, L.R. and FrICKER, A. 1987. Tectonostratigraphic terrane analysis of New Brunswick. Maritime Sediments and Atlantic Geology, 23, pp. 113-122.

Guber, A.L. and Merrill, S. III. 1983. Paleobathymetric significance of the foraminifera from the Hokuroku district. In The Kuroko and Related Volcanogenic Massive Sulphide Deposits. Edited by H. Ohmoto and B.J. Skinner. Economic Geology, Monograph 5, pp. 55-70.

IRRINKI, R.R. 1977a. Geology of Nictau, forks of Tobique River, J-9 (21 O/3E, 21 O/6E). New Brunswick Department of Natural Resources, Mineral Resources Branch, Plate 77-9. 1977b. Geology of Tobique-Bald Mountain-Riley and Neary Brooks, J-10 (21 O/3E). New Brunswick Department of Natural Resources, Mineral Resources Branch, Plate 77. 10. 1977c. Geology of North Gulquac-Stewart Brook-Blue Mountain Lake, J-11 (21 O/3E). New Brunswick Department of Natural Resources, Mineral Resources Branch, Plate 77. 11.

1977d. Geology of South Branch Gulquac River, J-12 (21 J/14E). New Brunswick Department of Natural Resources, Mineral Resources Branch, Plate 77-12.

LAmbert, I.B. and SATo, T. 1974. The Kuroko and associated ore deposits of Japan: a review of their features and metallogenesis. Economic Geology, 69, pp. 1215-1236.

Leat, P.T., Jackson, S.E., Thorpe, R.S., and Stillman, C.J. 1986. Geochemistry of bimodal basalt-subalkaline/peralkaline rhyolite provinces within the southern British Caledonides. Journal of the Geological Society, London, 143, pp. 259-273.

LOFGREN, G. 1971. Experimentally produced devitrification textures in natural rhyolitic glass. Geological Society of America Bulletin, 82, pp. 111-124.

LYDON, J.W. 1988. Ore deposit models-14. Volcanogenic massive sulphide deposits, part 2: genetic models. Geoscience Canada, 15, pp. 43-65.

McCutcheon, S.R. 1990. Base metal deposits of the BathurstNewcastle district. In Field Guide to Massive Sulphide Deposits in Northern New Brunswick. Edited by L.R. Fyffe. New Brunswick Department of Natural Resources and Energy, Minerals and Energy Division, pp. 42-71.

McCutcheon, S.R. and Bevier, M.L. 1990. Implications of field relations and $\mathrm{U}-\mathrm{Pb}$ geochemistry for the age of gold mineralization and timing of Acadian deformation in northern New Brunswick. Atlantic Geology, 26, pp. 237-246.

Онмото, H. and Skinner, B.J. 1983. The Kuroko and related volcanogenic massive sulphide deposits: introduction and summary of new findings. In The Kuroko and Related Volcanogenic Massive Sulphide Deposits. Edited by H. Ohmoto and B.J. Skinner. Economic Geology Monograph 5, pp. 1-8.

Pearce, J.A. 1982. Trace elements characteristics of lavas from destructive plate boundaries. In Andesites: Orogenic Andesites and Related Rocks. Edited by R.S. Thorpe. J. Wiley and Sons, Incorporated, United Kingdom, pp. 525-548.

Pearce, J.A., Harris, N.B.W., and Tindle, A.G. 1984. Trace element discrimination diagrams for the tectonic interpretation of granitic rocks. Journal of Petrology. 25, pp. 956-983.

Pearce, J.A., Bender, J.F., Delong, S.E., Kidd, W.S.F., Low, P.J., Guner, Y., Saroglu, F., Yilmaz, Y., Moorbath, S., and Mitchell, J.G. 1990. Genesis of collision volcanism in Eastern Anatolia, Turkey. Journal of Volcanology and Geothermal Research, 44, pp. 189-229.

Pichler, H. 1965. Acid hyaloclastites. Bulletin Volcanologique, 28, pp. 293-310.

Pickerill, R.K. 1986. Stratigraphy, sedimentology and structural analysis of the geology of the Tobique Reserve lands with an economic assessment of its geologic resources. Department of Indian and Northern Affairs, Ottawa, Ontario, unpublished report, $61 \mathrm{p}$.

RIDGE, J.D. 1973. Volcanic exhalations and ore deposition in the vicinity of the seafloor. Mineralium Deposita, 8, pp. 332 348.

Ross, C.S. and Smith, R.L. 1961. Ash-flow tuffs: their origin, geologic relations and identification. United States Geological Survey, Professional Paper 366, 81 p.

SACKs, P.E. and Secor, D.T., Jr. 1990a. Delamination in collisional orogens. Geology, 18, pp. 999-1002.

1990 b. Kinematics of late Paleozoic continental collision 
between Laurentia and Gondwana. Science, 250, pp. 1702 1705.

St. Peter, C. 1978. Geology of head of Wapske River, map-area J-13 (21 J/14). New Brunswick Department of Natural Resources, Mineral Resources Branch, Map Report 78-1, 24 p.

1979. Geology of Wapske-Odell River-Arthurette region, New Brunswick, map-areas I-13, I-14, H-14 (parts of $21 \mathrm{~J} / 11$, $21 \mathrm{~J} / 12,21 \mathrm{~J} / 13,21 \mathrm{~J} / 14$ ). New Brunswick Department of Natural Resources, Mineral Resources Branch, Map Report 79-2, $32 \mathrm{p}$.

1981. Geology of North Branch Southwest Miramichi River, map-areas J-14, J-15, J-16 (parts of $21 \mathrm{~J} / 11 \mathrm{E}, 21 \mathrm{~J} /$ 14E). New Brunswick Department of Natural Resources, Mineral Resources Branch, Map Report 80-1, 61 p.

Shanks, W.C., III and Bischoff, J.L. 1980. Geochemistry, sulfur isotope composition, and accumulation rates of Red Sea geothermal deposits. Economic Geology. 75, pp. 445-459.

SHERIDAN, M.F. 1979. Emplacement of pyroclastic flows: a review. Geological Society of America Special Paper 180, pp. 125-135.

Soloman, M. and Walshe, J.L. 1979. The formation of massive sulphide deposits on the sea floor. Economic Geology, 74, pp. 797-813.

Soper, N.J. and HutTon, D.H.W. 1984. Late Caledonian sinistral displacements in Britain: implications for a three-plate model. Tectonics, 3, pp. 781-794.

Van Der Pluijm, B.A. and Van Staal, C.R. 1988. Characteristics and evolution of the Central Mobile Belt, Canadian Appalachians. Journal of Geology, 96, pp. 535-547.

Von DAMm, K.L. 1990. Seafloor hydrothermal activity: black smoker chemistry and chimneys. Earth and Planetary Sciences, Annual Review, 18, pp. 173-204.

WILSON, R.A. 1988. Preliminary geology and lithogeochemistry of selected rock samples, Riley Brook map area, east half (NTS 21 O/3E), Victoria County, New Brunswick. New Brunswick Department of Natural Resources and Energy, Minerals and Energy Division, Geological Note Series PM $88-43,24$ p.

1989. Tobique project - Victoria, Restigouche, and Northumberland Counties, New Brunswick. In Project Summaries for 1989. Fourteenth Annual Review of Activities. Edited by S.A. Abbott. New Brunswick Department of Natural Resources and Energy, Minerals and Energy Division, Information Circular 89-2, pp. 18-27.

1990. Bedrock geology of the Riley Brook area, NTS 21 $\mathrm{O} / 3 \mathrm{E}$, part of $21 \mathrm{O} / 2 \mathrm{~W}$. New Brunswick Department of Natural Resources and Energy, Mineral Resources Division, Plate 90-162.

Winchester, J.A. and Floyd, P.A. 1977. Geochemical discrimination of different magma series and their differentiation products using immobile elements. Chemical Geology, 20, pp. 325-343.

Wright, J.V., Smith, A.L., and Self, S. 1980. A working terminology of pyroclastic deposits. Journal of Volcanology and Geothermal Research, 8, pp. 315-336.

Yamagishi, H. and Dimroth, E. 1985. A comparison of Miocene and Archean rhyolite hyaloclastites: evidence for a hot and fluid rhyolite lava. Journal of Volcanology and Geothermal Research, 23, pp. 337-355. 